\title{
The Ploskie Sopki Volcanic Massif: Geology, Petrochemistry, Mineralogy, and Petrogenesis (Klyuchevskoi Volcanic Cluster, Kamchatka)
}

\author{
G. B. Flerov*, T. G. Churikova, and V. V. Anan'ev \\ Institute of Volcanology and Seismology, Far East Branch, Russian Academy of Sciences, \\ bul'var Piipa, 9, Petropavlovsk-Kamchatskii, 683006 Russia \\ *e-mail:flerov@kscnet.ru \\ Received October 10, 2016
}

\begin{abstract}
This paper is concerned with the geological history and petrology of a major polygenic volcanic edifice dating back to Upper Pleistocene to Holocene time. This long-lived volcanic center is remarkable in that it combines basaltic and trachybasaltic magmas which are found in basaltic andesite and trachybasaltictrachyandesite series. The inference is that the coexisting parent magmas are genetically independent and are generated at different sources at depth in an upper mantle volume. The associated volcanic rocks have diverse compositions, stemming from a multi-stage spatio-temporal crystallization differentiation of the magmas and mixing of these in intermediate chambers.
\end{abstract}

DOI: $10.1134 / \mathrm{S} 0742046317040030$

\section{INTRODUCTION}

The information on the Ploskie Sopki massif can be found to varying degrees of detail in (Sirin, 1968; Piip, 1956; Ermakov, 1977; Flerov and Ovsyannikov, 1991; Churikova, 1990, 1993; Churikova and Sokolov, 1993; Churikova et al., 2001, 2012, 2013). Our studies supplied considerable corrections to the interpretation of the volcanic history for the formation of the massif and the associated petrogenesis. The Ploskie Sopki massif (Fig. 1) is the largest polygenic (as to morphology and geology) volcanic edifice in the Klyuchevskoi Volcanic Cluster. It is made of the paired edifices of the Late Pleistocene Ushkovskii (3943 m) and Krestovskii (4108 m) stratovolcanoes. The summit part of Ushkovskii Volcano and part of Krestovskii are truncated by a $4.5-\mathrm{km} \times 5.5-\mathrm{km}$ collapse caldera, which includes two cinder cones, Kherts and Gorshkov, and is filled with a glacier. Krestovskii Volcano is a fragment of the volcanic cone that has been spared by the collapse, and which makes up the N-NW-W steep wall of the collapse cirque. The slopes of the massif abound in cinder and cinder-lava cones due to parasitic eruptions at different hypsometric levels. Some of these are along the periphery of Ushkovskii Volcano, while most of the cones are confined to a narrow zone striking SSW-NNE-NE, which traverses the top of the massif and its slopes, and can be followed for a distance of $60 \mathrm{~km}$, with the width varying between 6 and $8 \mathrm{~km}$. One peculiar feature of the massif consists in the presence of normal and high alkalinity volcanic rocks within a single edifice, which exhibit a variety of structural aspects ranging between aphyric and megaplagiophyric. The present study draws upon material acquired for several sections of the volcano, with 237 chemical analyses of the rocks and 1540 analyses of the composition of rock-forming minerals.

\section{MATERIALS AND METHODS}

The analyses of the petrochemical compositions were mostly performed at the Institute of Volcanology and Seismology (IV\&S), Far East Branch, Russian Academy of Sciences (FEB RAS) by wet chemistry, with part of this work being carried out at the Vinogradov Institute of Geochemistry (IG), Siberian Branch (SB) RAS by the XRF technique. The compositions of rock-forming minerals were determined using a Camebax X-ray microanalyzer (at IV\&S FEB RAS) with an INCA installed energy dispersive spectrometer whose crystal had an area of $80 \mathrm{~mm}^{2}$. The current in the mode of the energy dispersive spectrometer at the $\mathrm{Ni}$ standard was $20 \mathrm{nA}$, the accelerating voltage was $20 \mathrm{kV}$, and the peak exposure was 15 seconds. The standards were blue diopside ( $\mathrm{Si}, \mathrm{Mg}, \mathrm{Ca}$ ), synthetic ilmenite $(\mathrm{Fe}, \mathrm{Ti})$, synthetic aluminum phosphate $(\mathrm{Al}, \mathrm{P})$, albite $(\mathrm{Na})$, orthoclase $(\mathrm{K})$, synthetic chromium oxide $(\mathrm{Cr})$, and rhodonite $(\mathrm{Mn})$. We studied polished sections of rocks and monomineral fractions larger than $0.25 \mathrm{~mm}$ across, which were selected from crushed samples as heavy as 300 grams. The method of mineral sampling was also used in order to obtain statistical 
$160^{\circ} 28^{\prime} \mathrm{E}$

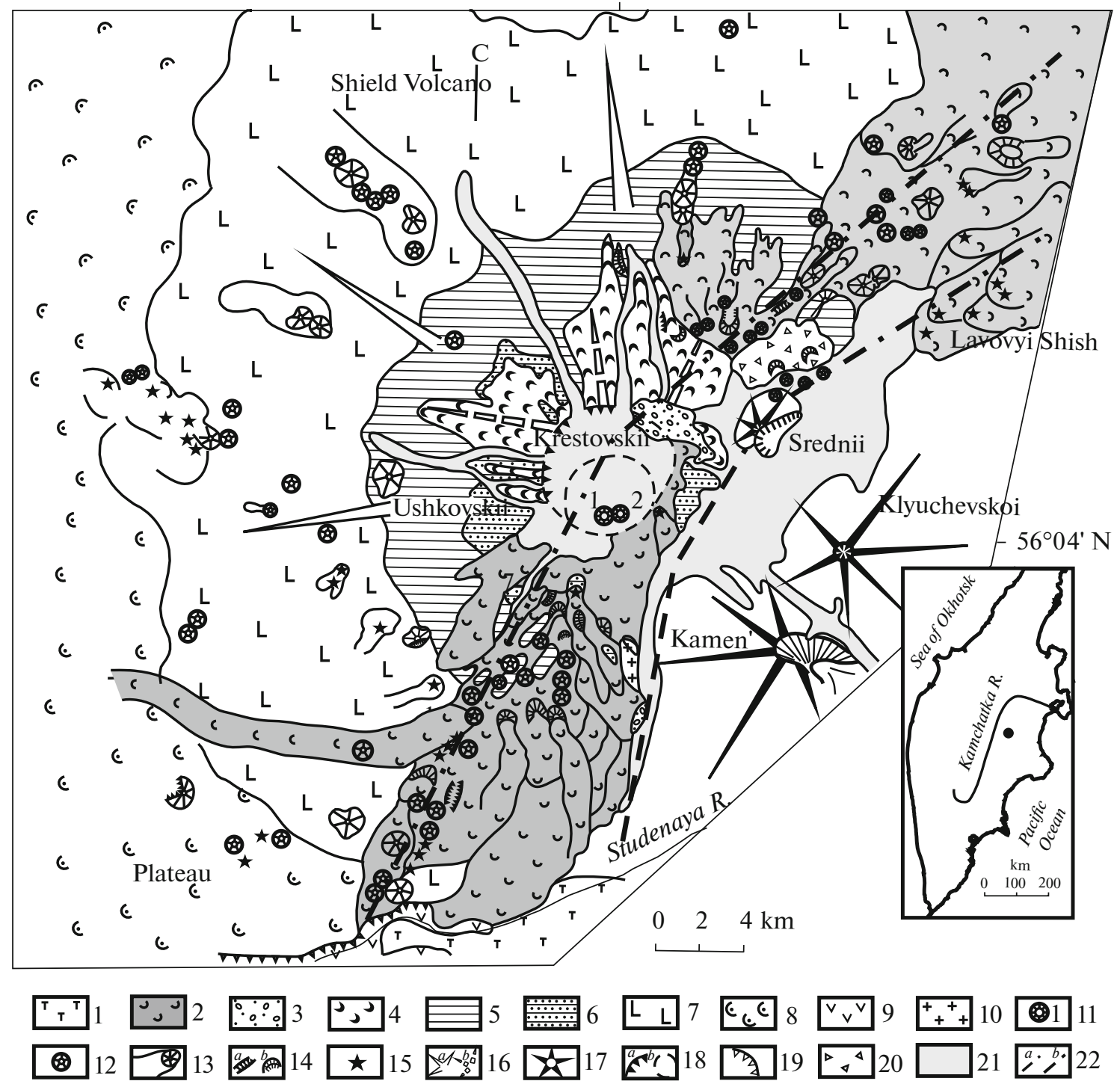

Fig. 1. A geological sketch map of the Ploskie Sopki massif.

Volcanic features: (1) in the Tolbachik areal zone $\mathrm{Q}_{4}$; $(2,3)$ Upper Pleistocene through Holocene $\mathrm{Q}_{3}^{3}-\mathrm{Q}_{4}$ features in the superimposed regional zone of cinder cones: cinder cones and lava flows of basaltic andesite and andesitic compositions with normal and higher alkalinity (2), agglomerate pyroclastic deposits due to intra-caldera eruptions, pyroclastic flows (3); (4-6) Upper

Pleistocene features due to the stratovolcanoes $Q_{3}^{3}$ : Krestovskii basalts $(4),(5,6)$ lava-pyroclastic features of basaltic and basaltic andesite compositions with normal and higher alkalinities due to Ushkovskii Volcano: rocks of various macro-textures (5), lavas

of the megaplagiophyric aspect (6); (7) Upper Pleistocene basalts due to the shield volcano $\mathrm{Q}_{3}^{2}$; (8) Middle Pleistocene features of the basement plateau $\mathrm{Q}_{2}$; (9) features in the basement of Ostryi Tolbachik and Ploskii Tolbachik stratovolcanoes; (10) Krasnyi Utes block outlier, basaltic andesites and andesites due to Ushkovskii stratovolcano; (11) the Kherts and Gorshkov cinder cones and cinder cones ( 1 and 2, respectively, in this figure) in the caldera; (12) other cinder cones; (13) features due to parasitic eruptions on Ushkovskii; (14) destroyed chains of craters $(a)$, destroyed cones $(b)$; (15) eruption centers; (16) Ushkovskii (a) and Krestovskii $(b)$ stratovolcanoes; (17) Klyuchevskoi, Kamen', and Srednii stratovolcanoes; (18) caldera scarps that have relief expression $(a)$ and that are buried in pyroclastic deposits and under a glacier $(b)$; (19) tectonic step on Studenaya R.; (20) moraines; (21) glaciers; (22) inferred faults: those having magma control on the eruptions in the regional zone of cinder cones $(a)$; the fault that caused normal movement in the eastern sector of stratovolcano edifices $(b)$. The geological sketch map of the massif is based on maps in (Sirin, 1968; Flerov and Ovsyannikov, 1991). The inset shows the location of the massif. 
information on phenocryst minerals, which were rare in polished sections.

\section{A GEOLOGICAL REVIEW}

The Ploskie Sopki massif stands on an extensive gently sloping volcanic plateau whose surface is at $\sim 1000 \mathrm{~m}$ altitude. Its deposits as thick as $200 \mathrm{~m}$ are occasionally exposed in a section of the steep scarp of the right-hand wall of the Studenaya R. canyon (Churikova et al., 2015a, Fig. 3). The plateau rocks are trachybasalts and basaltic trachyandesites; they exhibit a wide variety of texture, ranging from aphyric to large-grain porphyry varieties. The latter include megaplagiophyric lavas whose exposures are also found at considerable distances from the center of the volcano, being exposed in the basements of Ziminy Sopki and Bezymyannyi volcanoes, as well as in the walls of the Kamchatka River. According to its structure and composition this rock mass is a stratotype of the Khapichen plateau (Ermakov, 1977); ${ }^{40} \mathrm{Ar} /{ }^{39} \mathrm{Ar}$ determinations give an age fitting the Middle Pleistocene: a sample from the Khapichen plateau has an age of $274 \pm 8 \mathrm{ka}$ and that from the Studenaya section is 262 ka (Calkins, 2004).

The formation of the entire Ploskie Sopki massif as a long-lived volcanic center (see Fig. 1) was determined to have occurred during Upper Pleistocene through Early Holocene time $\mathrm{Q}_{3}^{2}-\mathrm{Q}_{4}^{1}$ (Braitseva et al., 1995; Ponomareva et al., 2013; Bazanova et al., 2016) and was at first thought to have been related to the activity of a large shield volcano $\left(\mathrm{Q}_{3}^{2}\right)$ (referred to in what follows as the shield volcano). This shield volcano stands on the plateau rocks and is composed of effusions of basaltic magma. It was the predecessor of the Ushkovskii stratovolcano, which has inherited its eruption center. The shield volcano has a diameter of $\sim 40-50 \mathrm{~km}$; the top of its lava flows dips at approximately $8^{\circ}-10^{\circ}$.

Ushkovskii Volcano $\left(\mathrm{Q}_{3}^{3}\right)$ stands out from the relief with its steep slopes dipping at $35^{\circ}-40^{\circ}$ and a step-like stratified structure; it shows a high degree of explosivity, and is composed of alternating lava flows and pyroclastic deposits. Its structure is very obviously dominated by basalts, which are typical in the basement of this edifice, giving way further upward to alternating basaltic-basaltic andesite and trachybasaltic-basaltic trachyandesite series. The section shows short flows and lenses of megaplagiophyric lavas whose compositions are like those just mentioned; these also terminate the section at the top in the shape of a wide mantle in the top parts of its western and eastern sectors (see Fig. 1). All the above rock varieties also occur in ejecta of parasitic vents.

The Krestovskii stratovolcano has a purely basaltic composition of its discharges. It was formed as the eruption center moved northward from the summit of
Ushkovskii Volcano; this seems to have occurred after a break in volcanic activity that was comparable with the period of glacial erosion. Its structures mostly concentrate in the northern sector of the massif and wedge out in the northwestern sector where basaltic flows overlie the upper sequence of the Ushkovskii megaplagiophyric basaltic andesites. The varieties whose phenocrysts are dominated by plagioclase are less abundant in the total mass of Krestovskii basalts, while megaplagiophyric lavas are only present in the Krestovskii dikes, which are probably conduits that supplied material for the post-caldera eruptions of the massif. At the same time, we encounter basalts enriched in high magnesia olivine and chromopicotite and basalts with high concentrations of titanomagnetite (up to $10 \%$ ).

Geological and geomorphologic studies gave the result that the shield volcano and the Ushkovskii and Krestovskii stratovolcanoes, as well as all the stratovolcanoes in the Klyuchevskoi Volcanic Cluster, were formed in the 40-60 ka time span (Melekestsev et al., 1970; Braitseva et al., 1995; Bazanova et al., 2016).

The Late Pleistocene through Early Holocene time was remarkable in that the geodynamic setting was changed in the region; the change manifested itself in tectono-magmatic activation that took place after a long period of relative quiescence. The central-type volcanism that had produced the stratovolcanoes gave way to fissure-type volcanism. The leading structural and magma-controlling element of volcanic occurrences is an arcuate fault striking nearly east-west to northeast; it traverses the volcanic massif and passes through the summits of both stratovolcanoes. The geotectonic processes have produced two collapse calderas within the massif; these collapses have destroyed the summit part of Ushkovskii Volcano and part of Krestovskii Volcano; a graben was formed on the S-SW slope of Ushkovskii Volcano together with extant outliers, or blocks of the Ushkovskii edifice. A large collapse in the eastern sector of the massif occurred to expose a section of the stratovolcano deposits, along with other secondary tectonic movements. Eruptions were occurring throughout the entire length of the fault zone to generate a volcanic zone (a regional zone of cinder cones) with numerous cinder and cinderlava cones and areal effusions of basaltic trachyandesite and trachyandesitic lavas that had filled both calderas and the graben. This character of volcanic occurrences is similar to Hawaiian "rifts," and is especially noticeable in a similar Holocene dispersed zone of cinder cones in the Tolbachik Dol, which is still active today (Braitseva et al., 1984; Flerov et al., 2015). Later volcanic activity mostly concentrated in the caldera and in the SW part of the fissure zone. The caldera was completely filled with lava, producing a shield upland with the Kherts and Gorshkov cinder cones of basaltic andesite compositions, while its flows made a mantle over the stratovolcano in its southern and eastern sectors. The caldera lavas are mostly rocks with megapla- 
giophyric and mesoplagiophyric textures. Effusions of megaplagiophyric lavas that seem to have been simultaneous with the caldera lavas also occurred during the effusive eruption on the Lavovyi Shish group of cones $\sim 20 \mathrm{~km}$ northeast of the caldera rim in the fissure zone at the N-NE foot of Klyuchevskoi Volcano (see Fig. 1). The zone of cinder cones was formed in the Late Pleistocene through Early Holocene time span: the ${ }^{40} \mathrm{Ar} /{ }^{39} \mathrm{Ar}$ age of a lava sample from early eruptions was dated $25 \mathrm{ka}$, while tephrogeochronologic studies give the age of the last eruptions as $8600-1100{ }^{14} \mathrm{C}$ years BP (Calkins, 2004; Ponomareva et al., 2013; Bazanova et al., 2016).

The entire volcanic edifice is cut through by numerous dikes of various ages; the rocks are the same varieties as the rocks of the entire massif. The intracaldera explosive eruptions during the early stage produced deposits of agglomerate pyroclastic flows with rock fragments (up to $30 \%$ of the volume) from a section of the volcano which were recorded on the outer and inner slopes of the caldera wall and are fragmentarily exposed beneath younger lava flows at the southern foot of the massif, making a rock sequence as thick as $40 \mathrm{~m}$. These deposits, as well as the mesoplagiophyric trachyandesite of the caldera lava flow, were found to contain xenoliths of volcanogenic-sedimentary rocks, amphibolites, gabbroids, and broken-down olivinites. To sum up, the geologic structure and evolution of the massif allow one to treat the entire variety of volcanic rocks as a single totality that is paragenetically related to the multistage evolution of the volcano's magmatic system in space and time.

\section{THE PETROCHEMISTRY}

Unpublished analyses of the present authors supplemented with those from (Churikova and Sokolov, 1993; Churikova, 1993; Ivanov, 2008) were used to make petrochemical diagrams. Representative chemical compositions for rocks sampled in the Ploskie Sopki massif are listed in Table 1. It appears from the diagrams in Fig. 2 that all volcanic rocks in the massif generally plot in a single common field. The compositions form a continuous series with regard to silica/alkalinity in the $\mathrm{SiO}_{2} 49-60 \mathrm{wt} \%$ interval with a trend to progressively increasing total alkalies (mostly $\mathrm{K}_{2} \mathrm{O}$ ). However, the distribution of data points and their positions in the diagrams for rock varieties sampled from different geologic features, which represent different stages of volcanism in the geological history of the massif, lend themselves to identification of two petrochemical rock series. All the rocks are calc-alkaline. Considering their total alkalies, they are normal and moderate alkaline varieties (referred to as higher alkalinity in the main text), while the concentration of $\mathrm{K}_{2} \mathrm{O}$ classifies them as moderate potassium and high potassium varieties. The normal alkaline rocks are basalts, less frequently basaltic andesites and andes- ites. Basalts are the most widespread rock type in the massif, they compose the shield volcano and Krestovskii, and dominate Ushkovskii; andesites are only found among some features on the zone of cinder cones. Rocks of higher alkalinity are trachybasalts, basaltic trachyandesites, and trachyandesites. Trachybasalts and basaltic trachyandesites are prevalent in the basement plateau and in the Ushkovskii stratovolcano; trachyandesites are found in insignificant amounts there, while the zone of cinder cones is dominated by trachyandesites (see Fig. 2).

The regression lines for the rocks of normal and higher alkalinity are nearly parallel. These sets of rocks show a linear distribution of compositional points with a positive correlation between alkalies and $\mathrm{SiO}_{2}$, while their positions in the diagrams of Fig. 2 demonstrate the relative discreteness of normal and highly alkaline rocks. The rocks of normal alkalinity make a trend in the interval of $\mathrm{SiO}_{2} 49-55 \%$, while the rocks of higher alkalinity in the Ushkovskii stratovolcano and in the zone of cinder cones make a single common set whose overall trend is within $\mathrm{SiO}_{2} 51-57 \%$ and $53-60 \%$, respectively. The Ushkovskii rocks show stepwise increases in alkalinity in the $51-54 \% \mathrm{SiO}_{2}$ interval through intermediate varieties; the increase is from 4 wt $\%$ to 5.6 wt $\% \mathrm{Na}_{2} \mathrm{O}+\mathrm{K}_{2} \mathrm{O}$, which allows one to identify two orthogonal trends, viz., basalt to trachybasalt and basaltic andesite to basaltic trachyandesite (unfilled arrows in Fig. 2). Basaltic andesites and andesites also form individual lava flows in the caldera and make up the intra-caldera cones of the Kherts and Gorshkov craters in the zone of cinder cones (see Figs. $2 \mathrm{a}$ and $2 \mathrm{~b}$, Table 1 , nos. 59, 60). It can be seen in the diagrams of Fig. 2 that the compositional field of rocks discharged by parasitic eruptions completely overlaps the Ushkovskii volcanic rocks, while the compositions of highly alkaline rocks sampled from the plateau and from the Ploskie Sopki massif plot within those for the Khapichen plateau.

Considering that the rock compositions are identi$\mathrm{cal}$, the analysis of the correlation diagram of oxides versus $\mathrm{SiO}_{2}$ (Fig. 3) places the emphasis on comparisons between compositions in accordance with the petrochemical series of normal and higher alkalinity. According to the concentration of silica, most of the volcano rocks are silicic and high silica varieties, being characterized by concentrations of that element between $16 \%$ and $20 \%$. However, Krestovskii and Ushkovskii gave several high magnesia samples of basalt that contain 14-15 wt $\% \mathrm{Al}_{2} \mathrm{O}_{3}$ and 9-10 wt $\% \mathrm{MgO}$, respectively (see Figs. 3c, 3d). The overall picture that emerges from inspection of the diagrams of Fig. 3 is that rocks of normal and higher alkalinity compose a single common cluster of data points showing persistent correlative relationships in most of the diagrams. The substantial amounts of major elements are obviously related to the fact that the rocks sampled from the massif consist of lavas with an unusually wide 


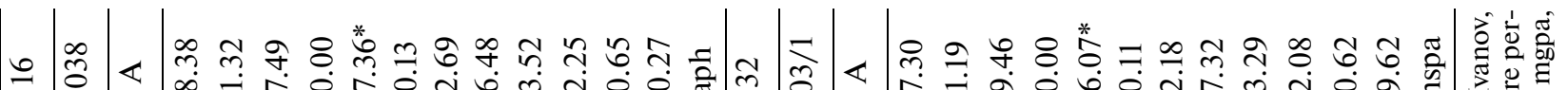

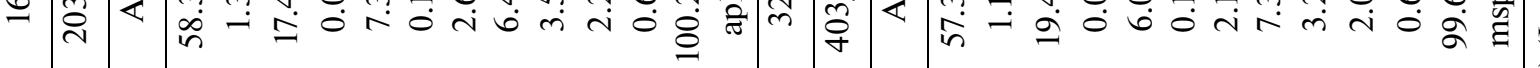

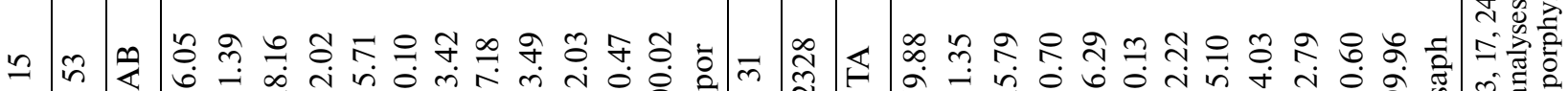
- nय

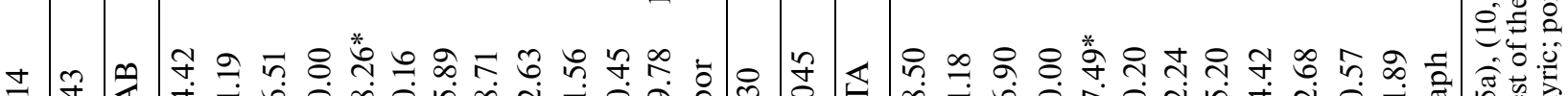

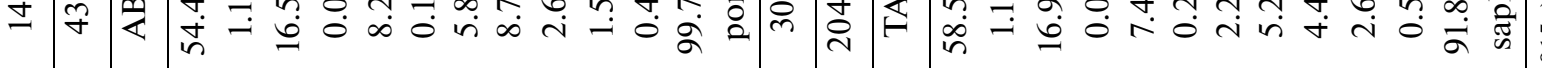

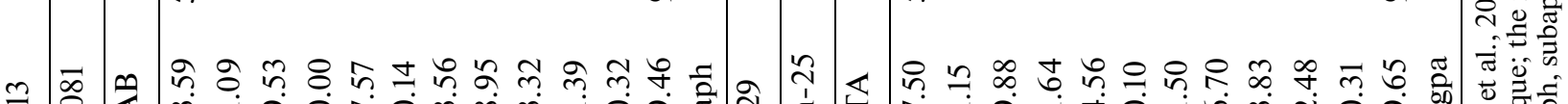

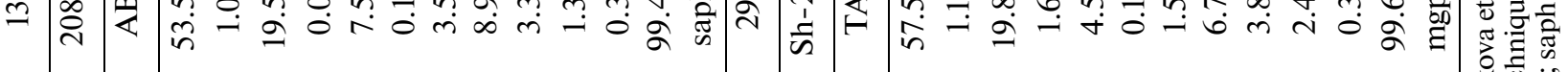
ฯ

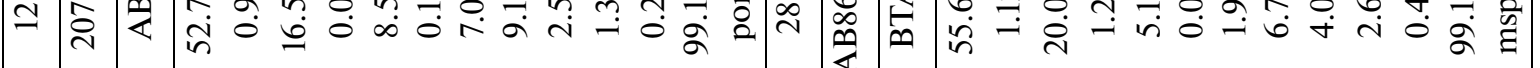

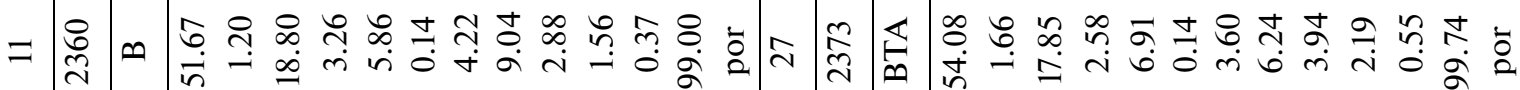
○ $=\varnothing \cong$ ป

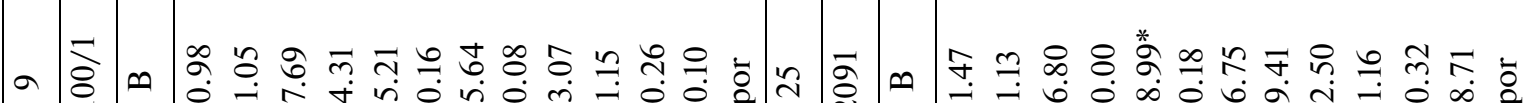

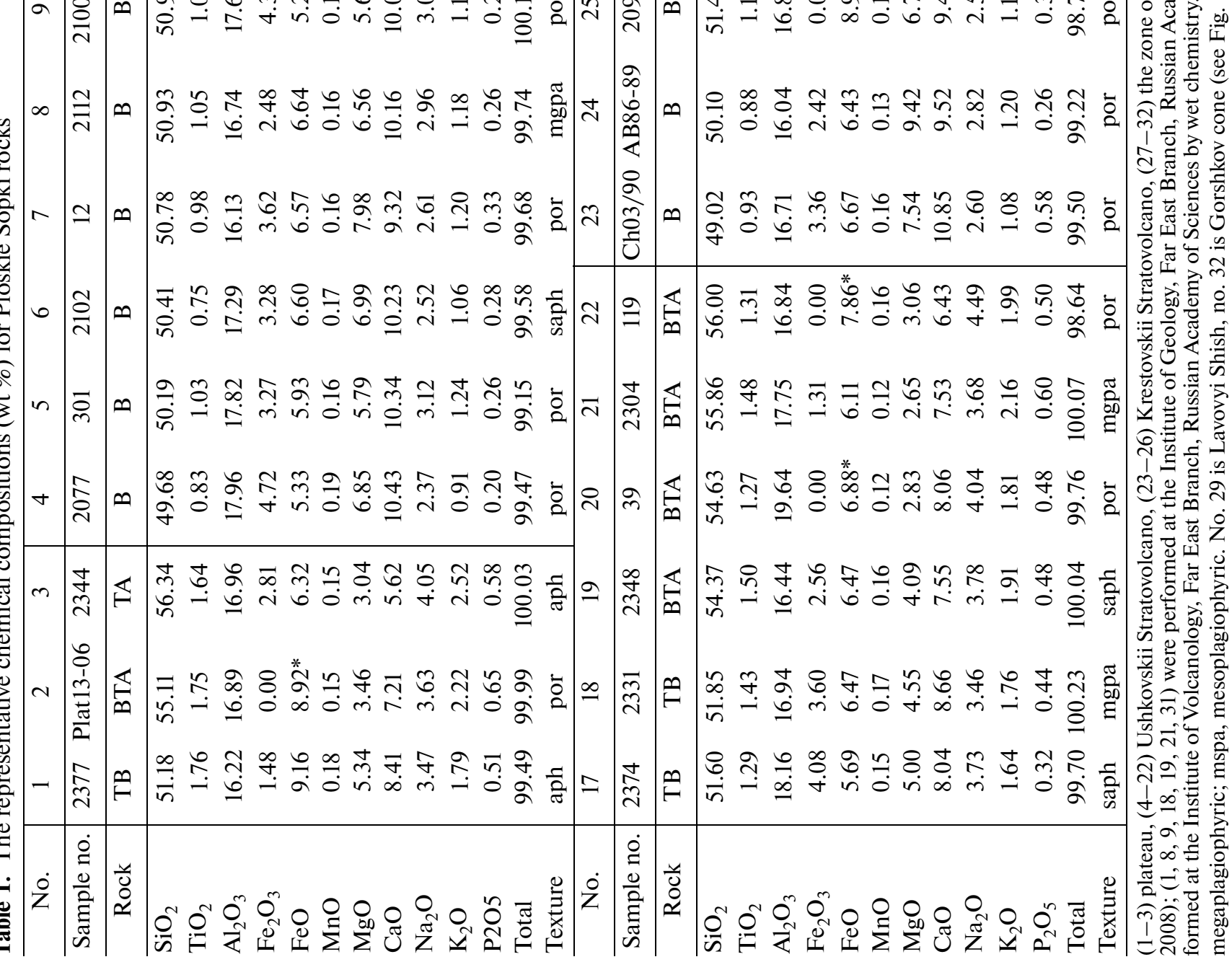




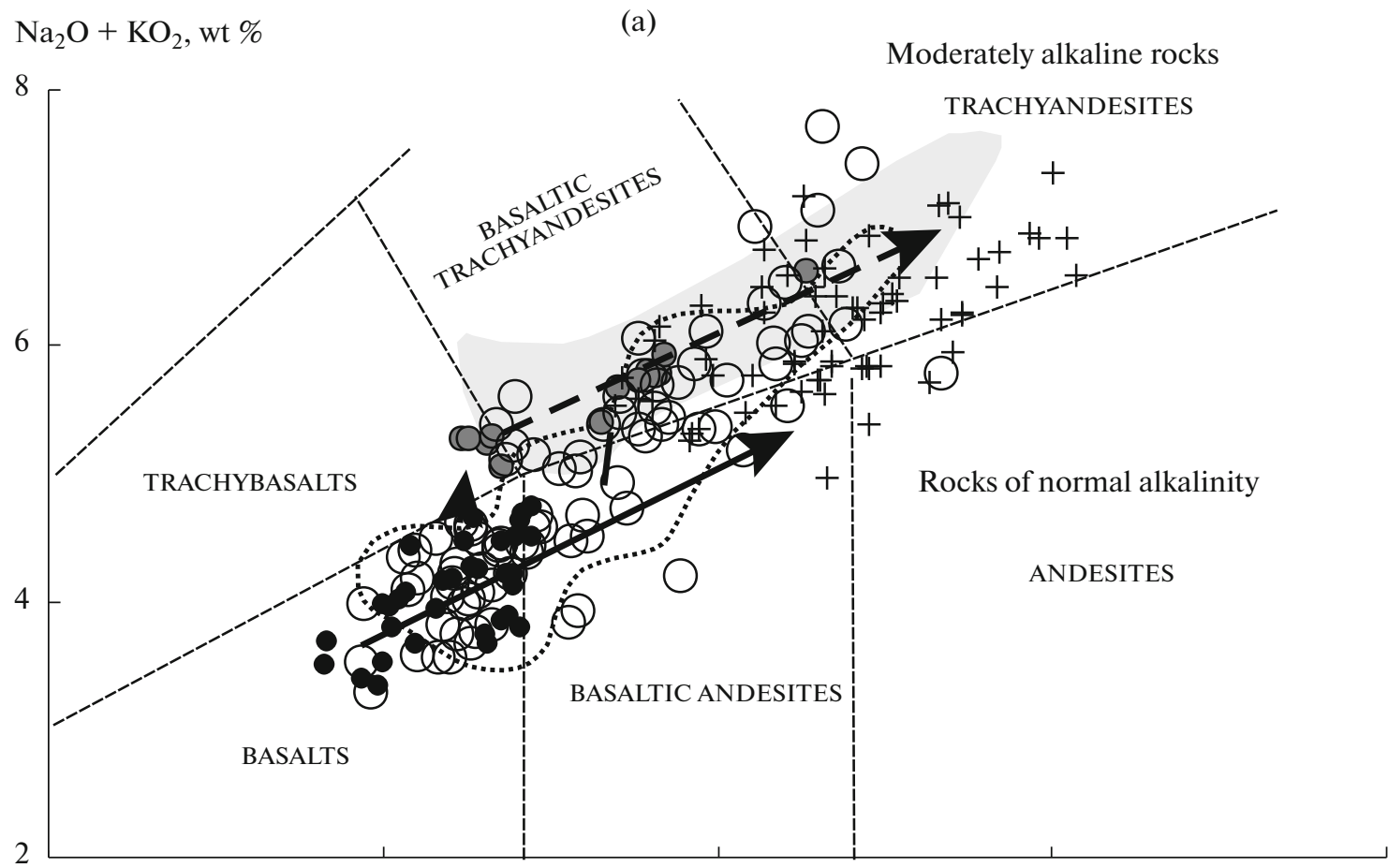

$\mathrm{K}_{2} \mathrm{O}$, wt \%

4

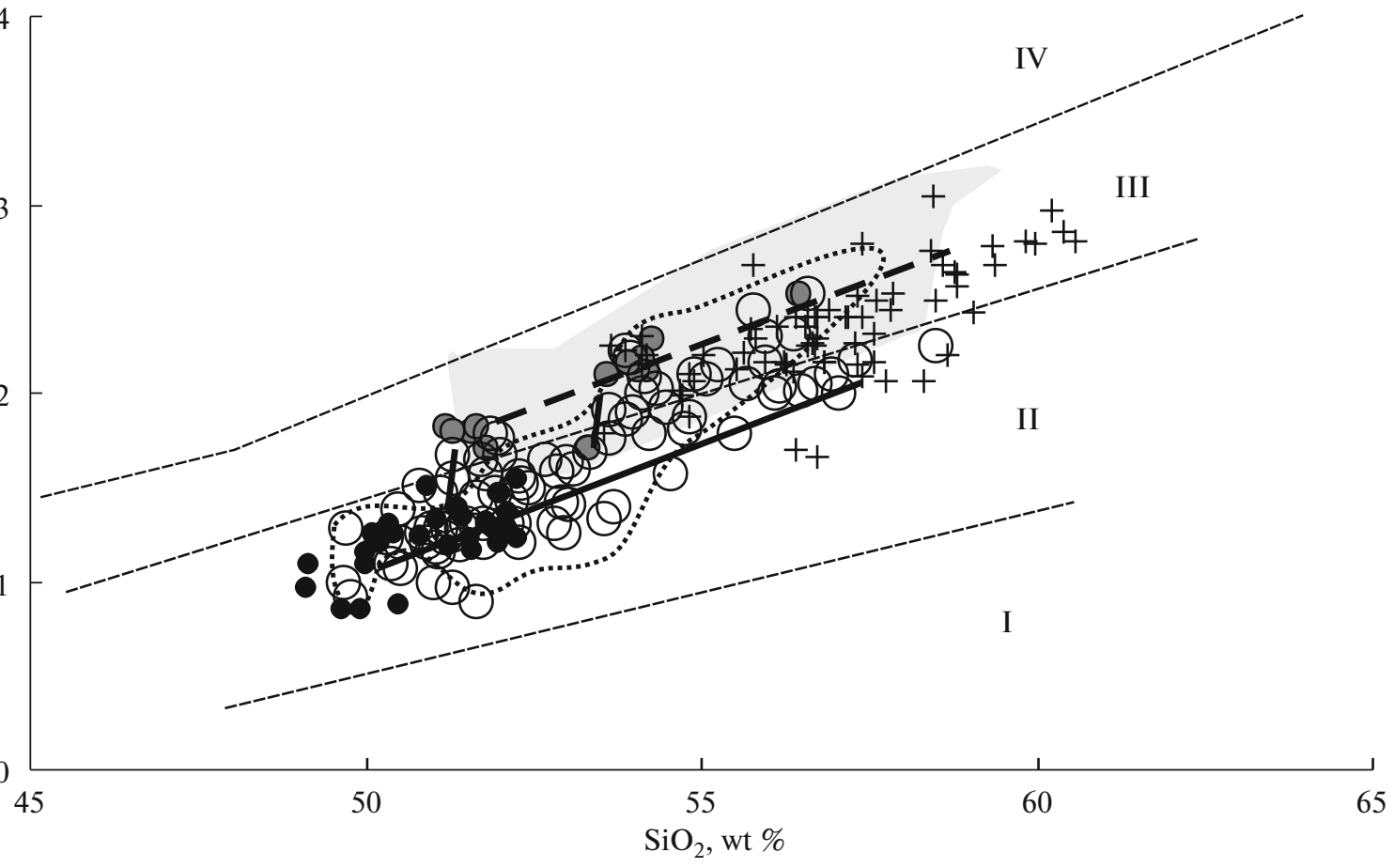

(b)

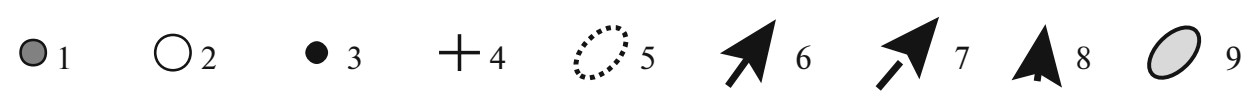

Fig. 2. The $\mathrm{SiO}_{2}-\mathrm{Na}_{2} \mathrm{O}+\mathrm{K}_{2} \mathrm{O}$ (a) and $\mathrm{SiO}_{2}-\mathrm{K}_{2} \mathrm{O}$ (b) classification diagrams for rocks sampled in the Ploskie Sopki massif. (1) basement plateau; (2-3) Ushkovskii (2) and Krestovskii (3) stratovolcanoes; (4) the regional zone of cinder cones; (5) compositional field of rocks discharged by parasitic eruptions; $(6,7)$ evolutionary trends for rocks of normal (6) and moderate (higher) alkalinity (7); (8) direction of alkalinity variation; (9) compositional field for rocks in the Khapichen plateau (Ermakov, 1977). Discrimination diagrams, after (Petrograficheskii kodeks ..., 2009; Peccerillo and Taylor, 1976). Roman numerals denote identification numbers of the following series: low potassium series (I), moderate potassium calc-alkaline series (II), high potassium calc-alkaline series (III), and subalkaline series (IV). 

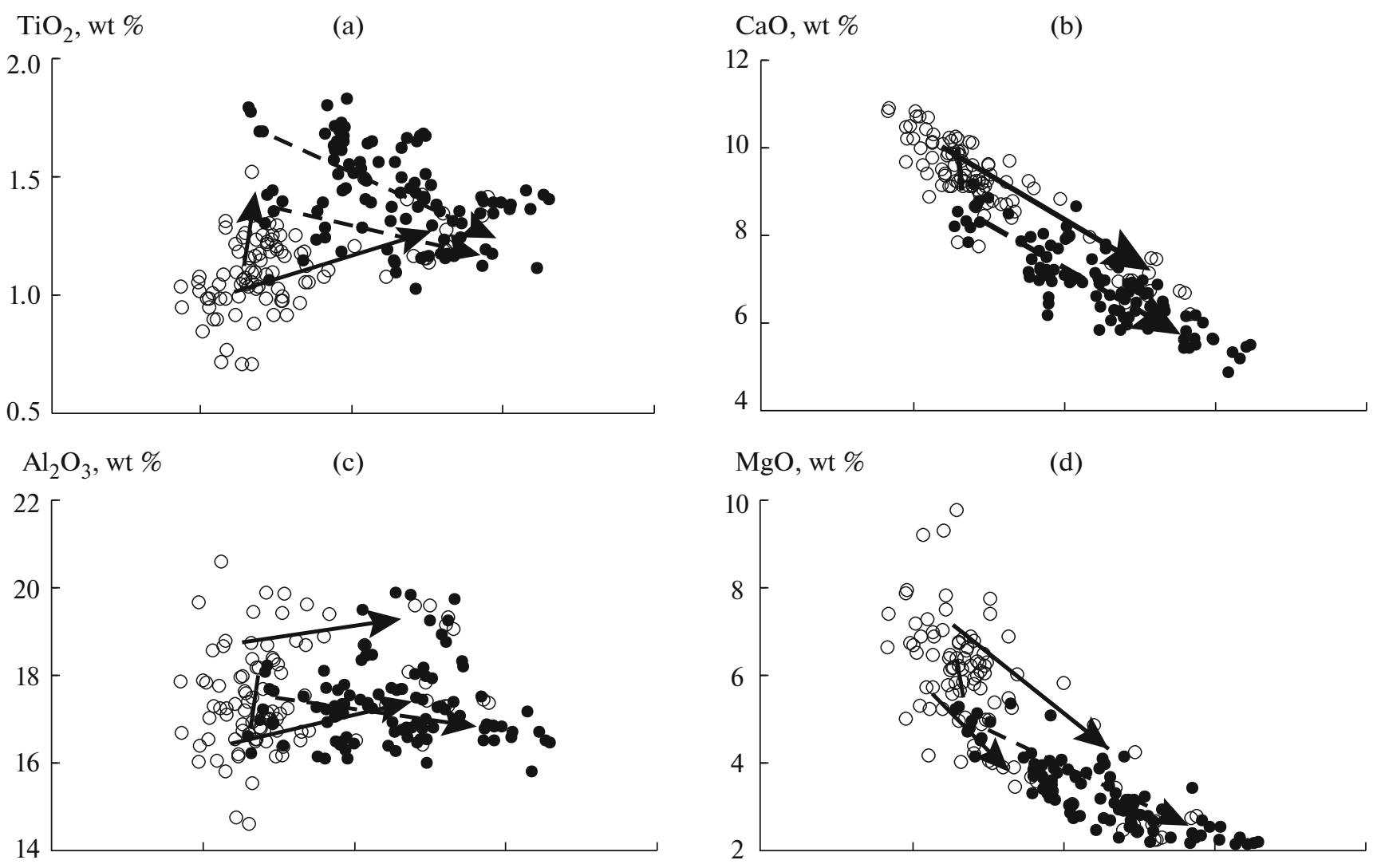

$\mathrm{MgO}$, wt \%

(d)
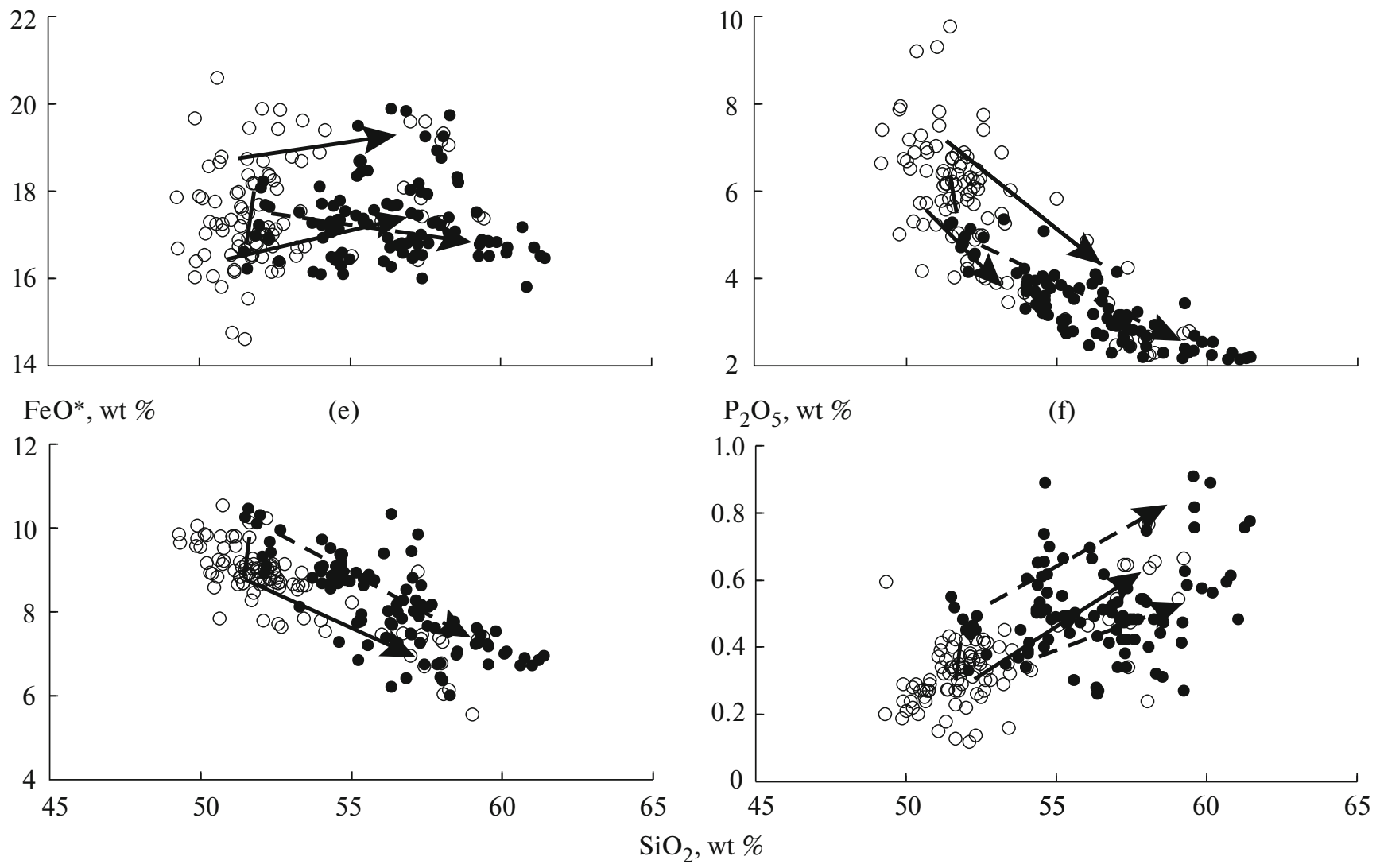

$0_{1} \bullet 2 \nearrow 3 \nearrow^{\top} 45$

Fig. 3. The $\mathrm{SiO}_{2}$ v. oxides Harker diagrams for the Ploskie Sopki rocks.

(1) rocks of normal alkalinity; (2) rocks of higher alkalinity; $(3,4)$ evolutionary trends for rocks of normal (3) and moderate (higher) alkalinity (4); (5) direction of alkalinity change.

range of textures (Cox et al., 1979). At the same time, careful examination will reveal certain differences in several diagrams between the distributions of data points for rocks of normal and higher alkalinity; this manifests itself in relative displacements of their fields and different orientations of the compositional regres- sion lines and the evolutionary trends of the rocks. Distinct differences are observed in the concentration of titanium in rocks of normal and higher alkalinity, which manifests itself in trends of, respectively, direct and reverse correlative relationships in the variation of $\mathrm{TiO}_{2}$ concentration (see Fig. 3a). The linear distribu- 
tions of data points showing more or less reliable correlation relative to $\mathrm{SiO}_{2}$ are noted for $\mathrm{MgO}, \mathrm{CaO}$, and $\mathrm{FeO}^{*}$, with the regression lines for the concentrations of these oxides in the rocks of normal and higher alkalinity series being oriented nearly parallel (see Figs. 3c-3f). Similarly to Fig. 2, the Ushkovskii basaltoids show two trends of variation for oxide concentrations, with the vector being from basalt to basaltic andesite in the one case and from basalt to trachybasalt in the other. The above features in the evolution of rock composition for various structural and age units in the Ploskie Sopki massif can be viewed as providing evidence of their common paragenesis.

\section{PETROGRAPHY AND MINERAL COMPOSITION}

The petrographic varieties of Ploskie Sopki volcanic rocks are controlled by variations of quantitative mineral relationships and by macrostructures ranging from aphyric to megaplagiophyric. The concentration of phenocrysts and subphenocrysts varies within the $5-50 \%$ range of rock volume, producing porphyry and serial porphyry textures. The absolute majority of all rock types, both of normal and higher alkalinity, shows the following mineral association of phenocrysts and subphenocrysts: plagioclase + olivine + clinopyroxene + titanomagnetite. The basalts contain both bipyroxene-olivine-plagioclase rocks and plagioclase varieties with sporadic phenocrysts of mafic minerals. The phenocrysts and subphenocrysts of mafic minerals are usually dominated by olivine. The concentration of orthopyroxene varies between the presence of sporadic crystals and $2-3 \%$ in the bipyroxene varieties of basalt. Rocks that are dominated by orthopyroxene are more rare; the high magnesia basalts of Krestovskii are substantially dominated by olivine. The rocks were found to contain polymineral $\mathrm{Ol}+\mathrm{Cpx}+\mathrm{Pl} \pm \mathrm{Opx} \pm \mathrm{TiMt} \pm \mathrm{Ilm}$ and monomineral glomerous growths. The trachybasalts contain clinopyroxene in substantially lower amounts; one notes olivine-plagioclase (oxygen-free) varieties. The ore mineral that is represented by the spinel group was found in both basalt types in phenocrysts, subphenocrysts, and as a guest mineral in phenocrysts consisting of olivine, pyroxene, and plagioclase; it is less abundant in basalts of normal alkalinity. The mineral association of microlites corresponds to that of phenocrysts, but is dominated by plagioclase, while pigeonite is encountered among microlites in basalts; the ore mineral is usually powdered in a glassy basis.

The mineral composition of the basaltic andesites and basaltic trachyandesites is similar to that for the basalt types described above. As the silica concentration increases in a rock it has smaller sizes and concentrations of mafic minerals, down to the presence of only some isolated grains; the amount of plagioclase becomes much greater, while the relative amount of clinopyroxene increases among the mafic minerals.
Orthopyroxene phenocrysts and subphenocrysts are a common occurrence in basaltic andesite; they are present in acidic varieties of basaltic trachyandesites. The microlite association is dominated by feldspar, the mafic minerals always include clinopyroxene, while basaltic andesites contain microlites of orthopyroxene and olivine, as well as pigeonite. The rocks of trachyandesitic compositions include bipyroxene-plagioclase and plagioclase varieties. Olivine is very rarely present in the form of individual small grains in polished sections or in crushed samples; the same can be said about pigeonite in groundmass. The accessory minerals include small apatite crystals, and very rarely amphibole in basaltic andesite and andesitic rocks.

According to its structure the Ushkovskii rocks include porphyry, subaphyric, and megaplagiophyric varieties, with porphyry varieties being usually present in Ushkovskii Volcano. The abundance of megaplagiophyric lavas somewhat increases from basalts to basaltic andesites and is greatly reduced in andesites.

More typical for the rocks in the zone of cinder cones are subaphyric, aphyric, and fine-porphyry macrotextures dominated by a plagioclase phase, a decidedly porphyry groundmass, and a glassy matrix, thus providing evidence of rapid crystallization. In addition, there are close-impregnated megaplagiophyric lavas that are typical of caldera effusions.

Olivines. Representative olivine compositions are listed in Table 2. It can be seen in the diagram of Fig. 4 that the phenocryst fields and the fields of olivine subphenocrysts from rocks of normal and higher alkalinity mostly overlap. Nevertheless, considering the statistics of the determinations, one can tentatively identify some differences in their compositions. The olivines from basalts and basaltic andesites, when considered with regard to the concentration of forsterite, make a comparatively continuous series in the Fo (\%) 88-56 interval with mass crystallization from Fo (\%) 83 (see Figs. 4a, 4b). The highest magnesia olivines $\mathrm{Fo}_{92-93}$, which seem to be the first liquidus phase of rock crystallization in the massif, are encountered only in the Krestovskii basalt and are characterized by lower values of $\mathrm{CaO}(0.12-0.13$ wt \%).

The olivines from trachybasalts and basaltic trachyandesites are characterized by a narrow range of forsterite concentration; their mass crystallization begins at $\mathrm{Fo}_{77}$. The variations in olivine composition from the trachyandesites sampled in the zone of cinder cones are in complete agreement with those of basaltic trachyandesites. Olivines of the Fo (\%) 84-85 composition are infrequently encountered in all types of rocks of higher alkalinity (see Figs. 4a, 4b). The positions of the microlite data points in the diagram (see Fig. 4b) suggests two nearly parallel trends in the compositional evolution of olivines, with normal (and high $\mathrm{CaO}$ ) and higher (and lower $\mathrm{CaO}$ ) alkalinity, respectively. We note that phenocrysts of olivine $\mathrm{Fo}_{83}$ from basalt were found to contain microinclusions of garnet 
Table 2. Representative compositions of olivine phenocrysts and subphenocrysts (wt \%) in rocks sampled from the Ploskie Sopki massif

\begin{tabular}{|c|c|c|c|c|c|c|c|c|c|c|c|c|c|c|}
\hline No. & 1 & 2 & 3 & 4 & 5 & $6^{*}$ & 7 & 8 & 9 & 10 & 11 & 12 & 13 & 14 \\
\hline Sample no. & \multicolumn{3}{|c|}{2377} & \multicolumn{2}{|c|}{2344} & \multicolumn{4}{|c|}{2102} & \multicolumn{3}{|c|}{2112} & \multicolumn{2}{|c|}{2081} \\
\hline Rock & TB & TB & $\mathrm{TB}$ & TA & TA & B & B & B & B & B & B & B & $\mathrm{AB}$ & $\mathrm{AB}$ \\
\hline $\mathrm{SiO}_{2}$ & 38.35 & 38.11 & 36.75 & 37.87 & 37.60 & 39.37 & 39.01 & 37.75 & 37.43 & 38.69 & 38.99 & 38.33 & 37.91 & 37.35 \\
\hline $\mathrm{FeO}$ & 21.24 & 24.28 & 28.25 & 25.29 & 27.10 & 15.82 & 18.29 & 24.22 & 27.28 & 20.04 & 21.21 & 25.05 & 18.92 & 23.67 \\
\hline $\mathrm{MgO}$ & 39.23 & 36.49 & 33.28 & 36.16 & 34.78 & 43.66 & 41.62 & 36.84 & 34.23 & 40.29 & 38.38 & 34.92 & 41.64 & 37.11 \\
\hline $\mathrm{CaO}$ & 0.20 & 0.24 & 0.24 & 0.17 & 0.19 & 0.18 & 0.19 & 0.26 & 0.23 & 0.22 & 0.26 & 0.25 & 0.22 & 0.21 \\
\hline $\mathrm{MnO}$ & 0.39 & 0.41 & 0.59 & 0.43 & 0.42 & 0.26 & 0.29 & 0.41 & 0.56 & 0.40 & 0.38 & 0.44 & 0.35 & 0.50 \\
\hline Total & 99.41 & 99.53 & 99.11 & 99.92 & 100.09 & 99.29 & 99.40 & 99.48 & 99.73 & 99.64 & 99.33 & 99.12 & 99.24 & 98.97 \\
\hline Fo, $\%$ & 76.70 & 72.82 & 67.74 & 71.82 & 69.58 & 83.11 & 80.22 & 73.06 & 69.10 & 78.18 & 76.33 & 71.31 & 79.69 & 73.65 \\
\hline No. & 15 & 16 & 17 & 18 & 19 & 20 & 21 & 22 & 23 & 24 & 25 & 26 & 27 & 28 \\
\hline Sample no. & \multicolumn{4}{|c|}{2374} & 2331 & \multicolumn{3}{|c|}{39} & \multicolumn{5}{|c|}{ AB86-89 } & 2328 \\
\hline Rock & TB & TB & TB & TB & TB & BTA & BTA & BTA & B & B & B & B & B & TA \\
\hline $\mathrm{SiO}_{2}$ & 38.86 & 38.79 & 38.39 & 38.79 & 38.03 & 37.88 & 36.17 & 37.48 & 41.22 & 40.71 & 39.87 & 39.69 & 40.40 & \begin{tabular}{|l|}
37.57 \\
\end{tabular} \\
\hline $\mathrm{FeO}$ & 20.49 & 21.23 & 22.86 & 22.23 & 24.88 & 25.09 & 29.46 & 28.34 & 6.48 & 7.65 & 10.25 & 14.65 & 15.77 & 28.14 \\
\hline $\mathrm{MgO}$ & 39.92 & 40.05 & 38.72 & 38.97 & 35.71 & 36.30 & 31.72 & 33.78 & 50.82 & 51.03 & 49.26 & 45.42 & 42.71 & 33.95 \\
\hline $\mathrm{CaO}$ & 0.14 & 0.16 & 0.23 & 0.19 & 0.24 & 0.19 & 0.23 & 0.26 & 0.06 & 0.10 & 0.16 & 0.15 & 0.22 & 0.17 \\
\hline $\mathrm{MnO}$ & 0.33 & 0.39 & 0.45 & 0.35 & 0.50 & 0.38 & 0.52 & 0.50 & 0.12 & 0.12 & 0.13 & 0.17 & 0.41 & 0.60 \\
\hline Total & 99.74 & 100.62 & 100.65 & 100.53 & 99.39 & 99.84 & 98.10 & 100.36 & 98.74 & 99.69 & 99.70 & 100.13 & 99.56 & 100.43 \\
\hline Fo, $\%$ & 77.60 & 77.08 & 75.12 & 75.76 & 71.46 & 72.06 & 65.75 & 68.00 & 93.20 & 92.13 & 89.42 & 84.53 & 82.46 & 68.26 \\
\hline
\end{tabular}

(1-5) plateau, (6-22) Ushkovskii Volcano, (23-27) Krestovskii Volcano, (28) zone of cinder cones.

B basalt, TB trachybasalt, BTA basaltic trachyandesite, TA trachyandesite. * a grain with a garnet inclusion.

(andradite) and melt inclusions: glass of trachyte composition $\left(\mathrm{SiO}_{2} 62 \mathrm{wt} \%\right.$ and $\left.\mathrm{Na}_{2} \mathrm{O}+\mathrm{K}_{2} \mathrm{O}, 11.7 \mathrm{wt} \%\right)+$ clinopyroxene crystals with high concentrations of $\mathrm{TiO}_{2}$ and $\mathrm{Al}_{2} \mathrm{O}_{3}$.

Spinellids. According to chemical composition we can distinguish two types of spinellids: chromopicotites and titanomagnetites with fluctuating concentrations of titanium, aluminum, and chromium (Table 3, Fig. 5). Chromopicotite, being a typomorphic mineral, with a high concentration of $\mathrm{Cr}_{2} \mathrm{O}_{3}(27-29 \mathrm{wt} \%)$ and $\mathrm{Al}_{2} \mathrm{O}_{3}$ (17 wt \%), was encountered as a guest mineral in olivine phenocrysts and as an independent phase in the Ushkovskii and Krestovskii basalts. It occupies an obviously discrete position in the diagram, thus providing evidence of intermittently stagelike crystallization. Titanomagnetites occur in all rock types of the massif, with the minerals from basalts being systematically enriched in chromium and aluminum compared with those from trachybasalts. A chromopicotite crystal and an inclusion of chromopicotite in olivine $\mathrm{Fo}_{85}$ were found in the monomineral fraction of trachyandesites in the zone of cinder cones and in the Ushkovskii basaltic trachyandesite (see Fig. 5).
Clinopyroxenes. The clinopyroxenes in phenocrysts and subphenocrysts from basalts and basaltic andesites are represented by the salite-augite series and their microlites by augite and pigeonite (Figs. 6a, 6d, Table 4). The minerals from rocks of higher alkalinity largely correspond with augite, while those from basaltic trachyandesites and trachyandesites have higher concentrations of the fayalite minal (see Figs. 6b, 6c, Table 4). Occasional salite grains were only found in monomineral fractions of crushed samples in rocks of higher alkalinity. The microlites make up the augitesubcalcium augite-pigeonite series (see Fig. d).

According to the $\mathrm{Mg}^{\#} \mathrm{Cpx}-\mathrm{Ti}$ relationship, the phenocryst clinopyroxenes from rocks of normal and higher alkalinity plot within the same field with a reverse correlative relationship that is typical of them (Fig. 7). However, the clinopyroxenes from rocks of normal alkalinity differ significantly from the clinopyroxenes from basalts of higher alkalinity by an originally longer regression line, which covers the field of high magnesia compositions during the earlier stages of crystallization, viz., the magnesium intervals of Cpx are 84-67 for basalts of normal alkalinity and 77-69 for basalts of higher alkalinity, respectively. Nevertheless, a single grain of high magnesia clinopyroxene 

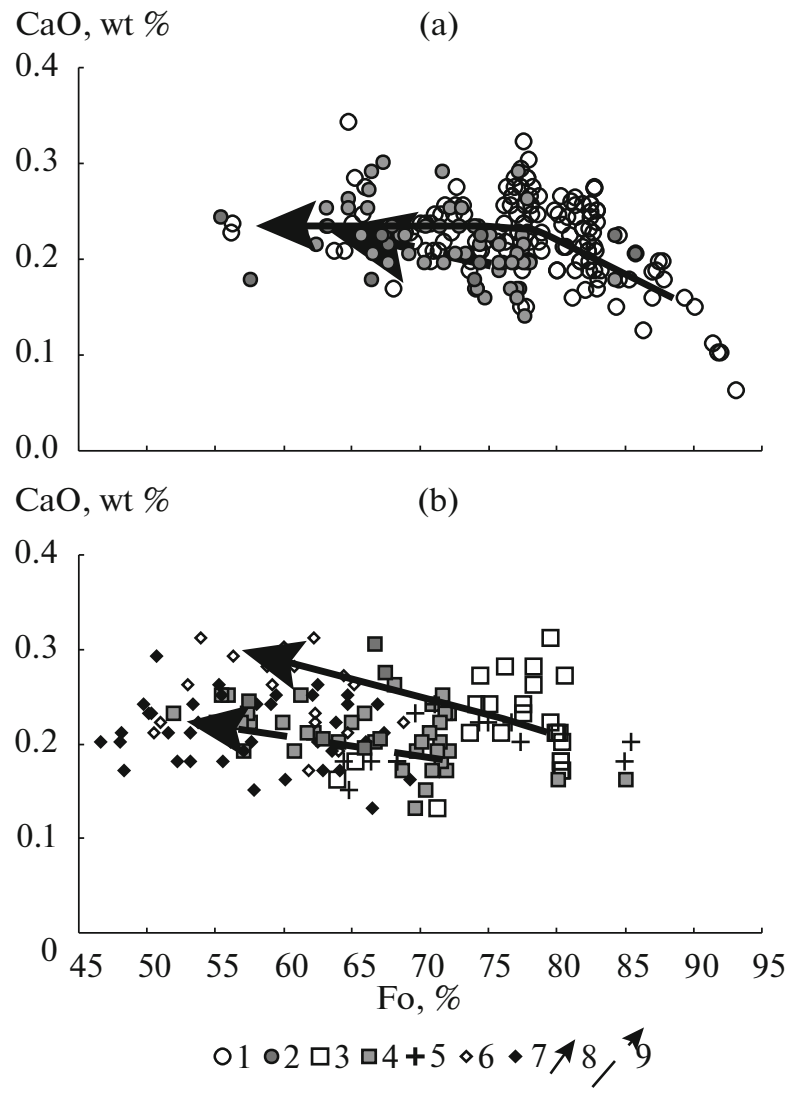

Fig. 4. The $\mathrm{Fo}-\mathrm{CaO}$ (wt \%) variation diagram for Ploskie Sopki basalts (a), and andesites and basaltic andesites (b).

(1) basalts, (2) trachybasalts, (3) basaltic andesites, (4) basaltic trachyandesites, (5) trachyandesites, (6) microlites of rocks of normal alkalinity, (7) microlites of rocks of higher alkalinity. Evolutionary trends for the composition of minerals in rocks of normal (8) and higher (9) alkalinity.

with $\mathrm{Mg}^{\#}=84$ was also encountered in a trachybasalt under study. Compared with the basalt clinopyroxenes, some Cpx from trachybasalts were enriched in $\mathrm{Ti}$, while the others occurred in the field of compositions where that element has a lower concentration.

The clinopyroxenes from basalts and basaltic andesites make a persistent trend 1 , which extends into the field of microlite data points (see Figs. 7a, 7b). Two sets can be seen among the clinopyroxenes from basaltic trachyandesites and trachyandesites on the background of a wide variability in the concentration of Ti (see Fig. 7b). One set of clinopyroxene points sampled among basaltic trachyandesites makes up trend 2, which is primarily coincident with or nearly parallel to that for basaltic andesites, but which involves a tendency of rapidly increasing concentration of $\mathrm{Ti}$, while the other (basaltic trachyandesites and trachyandesites) makes a nearly horizontal trend 3 from $\mathrm{Mg}^{\#} \mathrm{Cpx}=74$. Remarkably enough, the pigeonites in rocks of normal and higher alkalinity also differ in magnesia content: $\mathrm{Mg}^{\#} \mathrm{Pig}-63-67$ and 56-

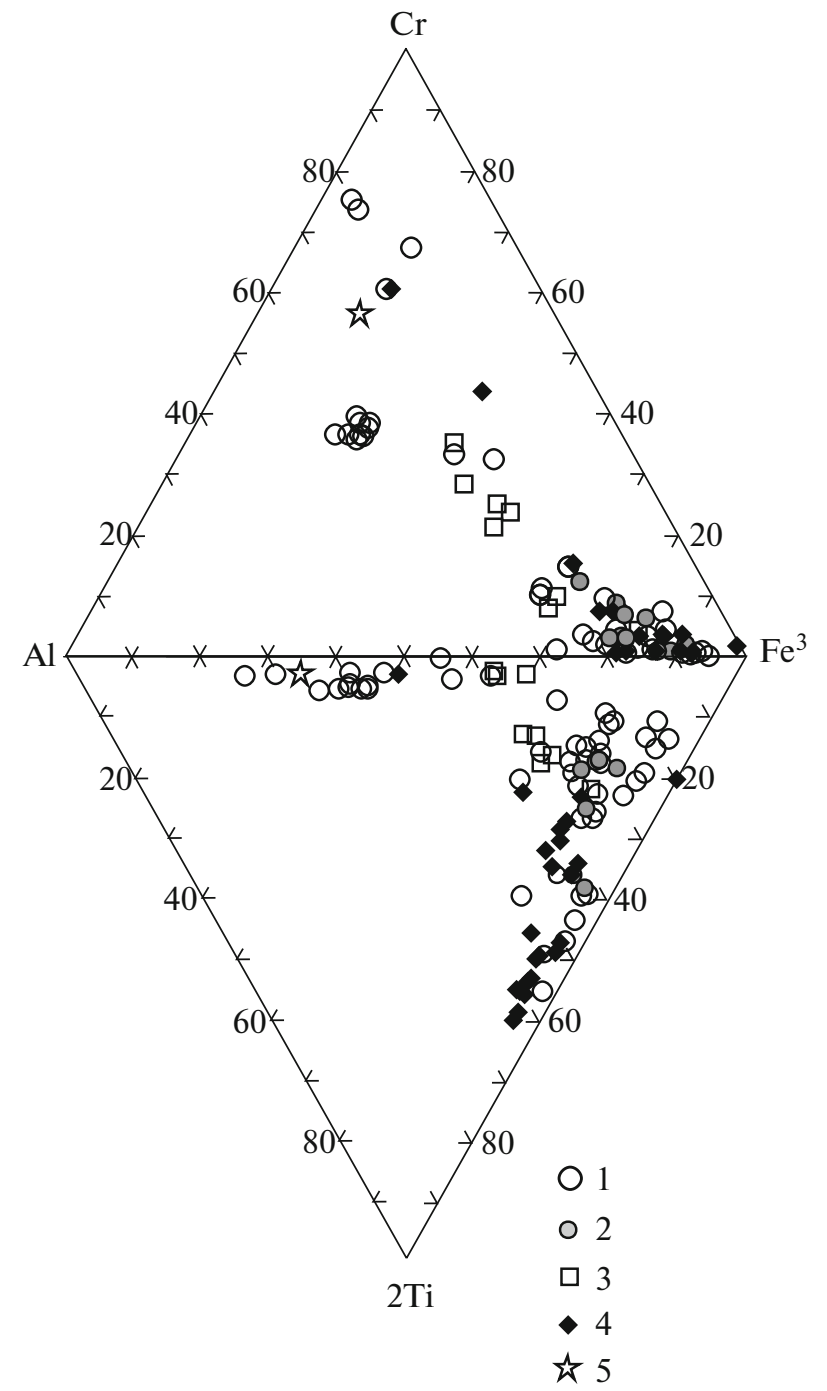

Fig. 5. The $\mathrm{Cr}-\mathrm{Al}-\mathrm{Fe}^{3}-\mathrm{Ti}$ compositional diagram (converted to cations) for spinellids in Ploskie Sopki rocks.

(1) basalts, (2) trachybasalts, (3) basaltic andesites, (4) basaltic trachyandesites, (5) chromopicotite from the mineral fraction of trachyandesite sampled from the zone of cinder cones. The cation concentration in the crystallochemical formula of the mineral is per 32 oxygen atoms.

61 , respectively. In addition, the basaltic trachyandesites and trachybasalts were found to contain only occasional grains of high magnesia clinopyroxenes with $\mathrm{Mg}^{\#}=80-85$ (see Fig. 7). Clinopyroxenes of the fassaite composition with abnormally high concentrations of titanium $\left(\mathrm{TiO}_{2}=1.6-2.2 \mathrm{wt} \%\right)$ and aluminia $\left(\mathrm{Al}_{2} \mathrm{O}_{3}=9.8-14.9 \mathrm{wt} \%\right)$ were encountered in a melt inclusion in olivine (see Table 2, Fig. 7a).

Orthopyroxenes are represented by the continuous bronzite-hypersthene series with the intervals $\mathrm{Mg}^{\#}$ Opx 78-68 and 75-62 in rocks of the basalt-basaltic andesite and basaltic trachyandesite-trachyandesite series, respectively (see Fig. 6). 
Table 3. Representative compositions of spinellids included in olivine (wt \%) from Ploskie Sopki rocks

\begin{tabular}{|c|c|c|c|c|c|c|c|c|c|c|c|c|c|c|}
\hline No. & 1 & 2 & 3 & 4 & 5 & 6 & 7 & 8 & 9 & 10 & 11 & 12 & 13 & 14 \\
\hline Sample no. & \multicolumn{2}{|c|}{2377} & \multicolumn{2}{|c|}{2102} & \multicolumn{3}{|c|}{3081} & \multicolumn{2}{|c|}{2374} & \multicolumn{2}{|c|}{39} & \multicolumn{3}{|c|}{ AB86-89 } \\
\hline Rock & TB & TB & B & B & BA & BA & $\mathrm{BA}$ & TB & TB & BTA & BTA & B & B & B \\
\hline$\overline{\mathrm{SiO}_{2}}$ & 3.09 & 0.00 & 0.16 & 0.00 & 0.00 & 0.00 & 0.00 & 0.00 & 0.00 & 0.21 & 0.23 & 0.27 & 0.00 & 0.20 \\
\hline $\mathrm{TiO}_{2}$ & 5.48 & 7.18 & 1.21 & 6.20 & 0.61 & 0.89 & 3.87 & 6.25 & 8.87 & 15.91 & 10.62 & 0.31 & 0.09 & 0.42 \\
\hline $\mathrm{Al}_{2} \mathrm{O}_{3}$ & 5.76 & 5.04 & 17.24 & 7.79 & 11.71 & 11.97 & 10.32 & 6.23 & 4.92 & 3.86 & 5.36 & 9.55 & 19.18 & 10.85 \\
\hline $\mathrm{Cr}_{2} \mathrm{O}_{4}$ & 6.06 & 4.71 & 28.25 & 1.45 & 25.35 & 14.94 & 16.55 & 1.93 & 3.52 & 2.81 & 3.32 & 54.75 & 16.67 & 45.24 \\
\hline $\mathrm{Fe}_{2} \mathrm{O}_{3}$ & 36.78 & 44.16 & 21.25 & 46.44 & 31.40 & 39.87 & 36.83 & 49.68 & 44.70 & 31.30 & 39.84 & 6.90 & 36.83 & 15.16 \\
\hline $\mathrm{FeO}$ & 35.92 & 34.92 & 23.21 & 32.17 & 23.43 & 23.85 & 25.85 & 32.05 & 35.54 & 41.30 & 38.02 & 15.67 & 13.32 & 18.83 \\
\hline $\mathrm{MnO}$ & 0.40 & 0.48 & 0.39 & 0.29 & 0.47 & 0.38 & 0.43 & 0.00 & 0.43 & 0.51 & 0.48 & 0.25 & 0.16 & 0.41 \\
\hline $\mathrm{MgO}$ & 2.43 & 1.77 & 7.86 & 3.23 & 6.48 & 6.06 & 6.92 & 3.84 & 2.93 & 3.05 & 2.48 & 11.41 & 13.82 & 9.74 \\
\hline Total & 95.92 & 98.26 & 99.57 & 97.57 & 99.45 & 97.96 & 100.77 & 99.98 & 100.91 & 98.96 & 100.35 & 99.14 & 100.07 & 100.85 \\
\hline $\mathrm{F} / \mathrm{FM}$ & 89.24 & 91.71 & 62.36 & 84.82 & 66.98 & 68.83 & 67.70 & 82.40 & 87.19 & 88.37 & 89.58 & 44.19 & 35.11 & 52.45 \\
\hline Fo, $\%$ & 76.70 & 72.82 & 80.22 & 73.06 & 79.69 & 79.69 & 79.69 & 77.08 & 77.60 & 72.06 & 68.00 & 92.13 & 84.53 & 89.42 \\
\hline
\end{tabular}

(1-2) plateau, (3-11) Ushkovskii Volcano, (12-14) Krestovskii Volcano. B, basalt; BA, basaltic andesite; TB, trachybasalt; BTA, basaltic trachyandesite. Fo, $\%$ denotes the concentration of forsterite minal in the host mineral.

Feldspars. The phenocrysts and subphenocrysts of all rocks consist of $\mathrm{Ca}-\mathrm{Na}$ plagioclase (Table 5). Figures $8 \mathrm{a}$ and $8 \mathrm{~b}$ show an evidently dominating set of plagioclase points, with normal and higher alkalinity and a good correlative relationship. A discreteness is noted within that field with an intermission in the $\mathrm{An}_{72-73}$ region in minerals from basalts and in the $\mathrm{An}_{64-73}$ region in trachybasalts (see Fig. 8a), providing evidence of intermittent stage-like crystallization of the associated rocks. The plagioclases at the earlier stages of basalt crystallization have basic compositions with the maximum concentration of the anorthite minal from $88 \%$, which are inherited in basaltic andesites, while in the plagioclases from trachybasalts one observes a higher concentration of the orthoclase component in the An 60-65\% interval (see Table 5, Figs. 8a, 8b). The plagioclases from basalts and basaltic andesites with different degrees of alkalinity both follow a common trend and form (equally as in Fig. 7) a fan-shaped series of differently sloping trends starting from the $\mathrm{An}_{60-65}$ composition (see Figs. 8a, 8b). In addition, the basalts and basaltic andesites of higher alkalinity contain a generation of plagioclase phenocrysts with concentrations of the orthoclase minal in the $0-0.1 \%$ interval that have never been observed in the rocks of higher alkalinity (see Figs. 8a, 8b). The

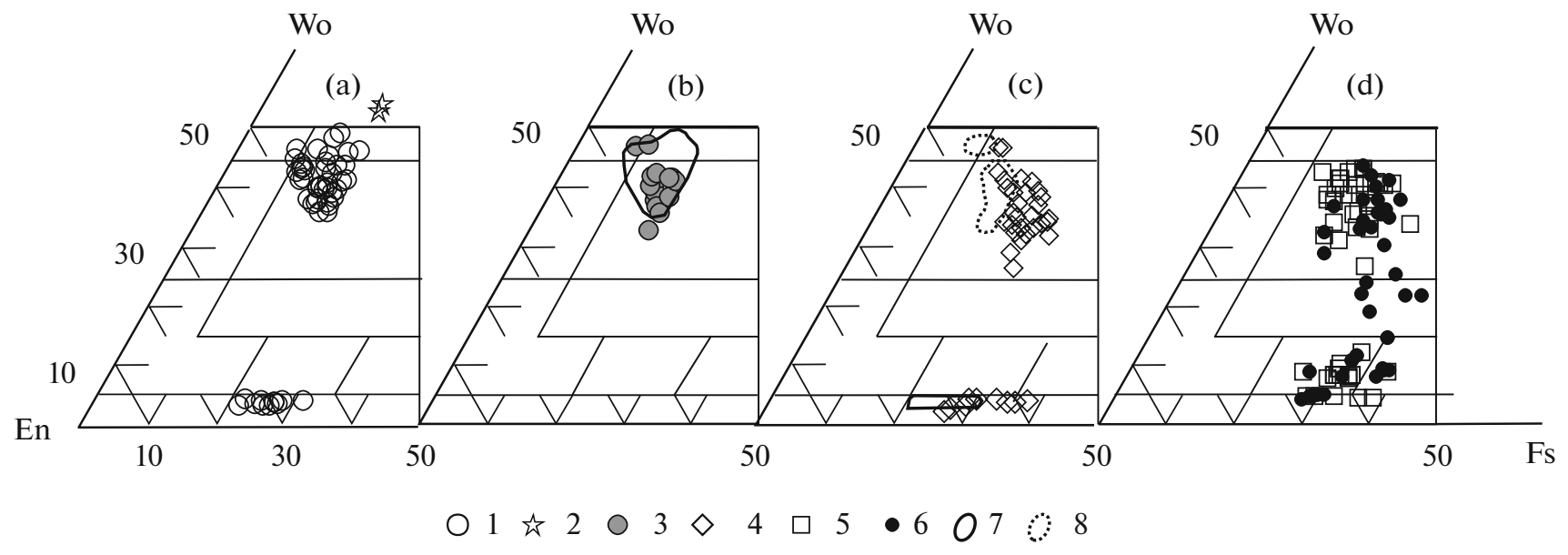

Fig. 6. The En-Wo-Fs classification diagrams for pyroxenes in Ploskie Sopki rocks.

$(\mathrm{a}-\mathrm{c})$ for phenocrysts and subphenocrysts, $(\mathrm{d})$ for microlites.

$(1,2)$ basalts and basaltic andesites from rocks (1) and from a melt inclusion (2); (3) trachybasalts; (4) basaltic trachyandesites and trachyandesites; (5) microlites in rocks of normal alkalinity; (6) microlites in rocks of higher alkalinity; (7) field of basaltic phenocrysts; (8) field of trachybasaltic phenocrysts. The discrimination diagrams are given after (Poldervaart and Hess, 1951). 
Table 4. Representative compositions of clinopyroxene phenocrysts and subphenocrysts (wt \%) from Ploskie Sopki rocks

\begin{tabular}{|c|c|c|c|c|c|c|c|c|c|c|c|c|c|}
\hline No. & 1 & 2 & 3 & 4 & 5 & 6 & 7 & 8 & 9 & 10 & 11 & 12 & 13 \\
\hline Sample no. & \multicolumn{3}{|c|}{2377} & \multicolumn{2}{|c|}{ Plato13-6 } & \multicolumn{4}{|c|}{2102} & \multicolumn{3}{|c|}{2112} & 2081 \\
\hline Rock & $\mathrm{TB}$ & TB & TB & BTA & BTA & B & B & B & B & B & B & B & $\mathrm{AB}$ \\
\hline $\mathrm{SiO}_{2}$ & 50.84 & 50.58 & 51.66 & 49.12 & 51.72 & 51.34 & 50.19 & 49.72 & 50.91 & 44.34 & 50.46 & 50.35 & 51.60 \\
\hline $\mathrm{TiO}_{2}$ & 0.77 & 0.79 & 0.67 & 1.43 & 0.90 & 0.30 & 0.53 & 0.63 & 0.62 & 1.60 & 0.73 & 0.73 & 0.46 \\
\hline $\mathrm{Al}_{2} \mathrm{O}_{3}$ & 2.80 & 2.37 & 2.17 & 3.70 & 1.72 & 3.00 & 3.96 & 4.03 & 2.68 & 11.46 & 3.69 & 4.16 & 3.01 \\
\hline $\mathrm{Cr}_{2} \mathrm{O}_{3}$ & 0.01 & 0.00 & 0.00 & 0.00 & 0.00 & 0.47 & 0.24 & 0.18 & 0.00 & 0.00 & 0.00 & 0.11 & 0.36 \\
\hline $\mathrm{FeO}^{*}$ & 9.06 & 10.69 & 8.45 & 11.06 & 10.95 & 5.51 & 6.95 & 8.84 & 10.69 & 7.53 & 8.91 & 9.07 & 6.52 \\
\hline $\mathrm{MnO}$ & 0.28 & 0.36 & 0.39 & 0.30 & 0.34 & 0.18 & 0.17 & 0.21 & 0.38 & 0.00 & 0.22 & 0.25 & 0.17 \\
\hline $\mathrm{MgO}$ & 14.96 & 14.84 & 15.69 & 13.77 & 15.87 & 16.12 & 14.50 & 14.53 & 14.68 & 11.89 & 15.85 & 14.59 & 16.21 \\
\hline $\mathrm{CaO}$ & 19.79 & 17.98 & 20.32 & 19.94 & 17.97 & 21.50 & 21.94 & 20.50 & 18.43 & 21.48 & 19.64 & 19.25 & 21.73 \\
\hline $\mathrm{Na}_{2} \mathrm{O}$ & 0.28 & 0.22 & 0.33 & 0.37 & 0.28 & 0.30 & 0.23 & 0.37 & 0.25 & 0.45 & 0.41 & 0.32 & 0.32 \\
\hline Total & 98.86 & 97.92 & 99.68 & 99.69 & 99.75 & 98.72 & 98.71 & 99.01 & 98.64 & 98.75 & 99.91 & 98.84 & 100.38 \\
\hline Woll & 41.50 & 38.28 & 41.69 & 41.78 & 36.98 & 44.58 & 46.15 & 43.05 & 39.05 & 48.93 & 40.37 & 41.29 & 44.01 \\
\hline En & 43.66 & 43.96 & 44.78 & 40.14 & 45.44 & 46.50 & 42.43 & 42.46 & 43.27 & 37.68 & 45.33 & 43.53 & 45.68 \\
\hline Fs & 14.84 & 17.77 & 13.53 & 18.09 & 17.59 & 8.92 & 11.41 & 14.49 & 17.68 & 13.39 & 14.30 & 15.18 & 10.31 \\
\hline $\mathrm{Mg} \#$ & 74.64 & 71.22 & 76.80 & 68.94 & 72.09 & 83.91 & 78.81 & 74.55 & 70.99 & 73.79 & 76.02 & 74.14 & 81.59 \\
\hline No. & 14 & 15 & 16 & 17 & 18 & 19 & 20 & 21 & 22 & 23 & 24 & 25 & 26 \\
\hline Sample no. & \multicolumn{3}{|c|}{2081} & \multicolumn{2}{|c|}{2374} & 2331 & \multicolumn{2}{|c|}{39} & \multicolumn{4}{|c|}{ A86-89 } & 2328 \\
\hline Rock & $\mathrm{AB}$ & $\mathrm{AB}$ & $\mathrm{AB}$ & TB & TB & TB & BTA & BTA & B & B & B & B & TA \\
\hline$\overline{\mathrm{SiO}_{2}}$ & 50.24 & 51.01 & 49.93 & 48.71 & 49.52 & 51.28 & 50.59 & 50.72 & 52.46 & 51.69 & 52.81 & 52.52 & 52.8 \\
\hline $\mathrm{TiO}_{2}$ & 0.72 & 0.79 & 1.02 & 1.30 & 1.02 & 0.45 & 1.24 & 1.15 & 0.40 & 0.65 & 0.28 & 0.19 & 0.65 \\
\hline $\mathrm{Al}_{2} \mathrm{O}_{3}$ & 3.81 & 2.48 & 3.64 & 4.62 & 3.56 & 2.83 & 2.31 & 2.40 & 2.54 & 3.52 & 2.77 & 2.62 & 2.08 \\
\hline $\mathrm{Cr}_{2} \mathrm{O}_{3}$ & 0.37 & 0.00 & 0.00 & 0.00 & 0.00 & 0.07 & 0.00 & 0.00 & 0.24 & 0.36 & 0.54 & 0.41 & 0.02 \\
\hline $\mathrm{FeO}^{*}$ & 7.24 & 9.73 & 11.20 & 10.60 & 9.87 & 9.64 & 12.98 & 12.28 & 7.26 & 7.99 & 6.30 & 4.86 & 9.22 \\
\hline $\mathrm{MnO}$ & 0.22 & 0.26 & 0.30 & 0.30 & 0.28 & 0.35 & 0.33 & 0.34 & 0.14 & 0.15 & 0.15 & 0.10 & 0.31 \\
\hline $\mathrm{MgO}$ & 15.46 & 16.23 & 15.92 & 14.18 & 14.41 & 15.86 & 14.06 & 15.56 & 16.21 & 15.33 & 16.72 & 16.27 & 14.32 \\
\hline $\mathrm{CaO}$ & 21.37 & 18.41 & 17.22 & 19.28 & 19.70 & 17.81 & 18.36 & 16.90 & 20.03 & 20.13 & 20.08 & 21.55 & 20.04 \\
\hline $\mathrm{Na}_{2} \mathrm{O}$ & 0.40 & 0.38 & 0.46 & 0.53 & 0.42 & 0.32 & 0.43 & 0.32 & 0.06 & 0.30 & 0.35 & 0.24 & 0.16 \\
\hline Total & 99.83 & 99.29 & 99.69 & 99.52 & 98.78 & 98.61 & 100.30 & 99.67 & 99.38 & 100.12 & 100.00 & 98.76 & 99.60 \\
\hline Woll & 44.03 & 37.89 & 35.79 & 40.78 & 41.51 & 37.58 & 38.21 & 35.11 & 41.52 & 42.21 & 10.19 & 7.91 & 42.50 \\
\hline En & 44.32 & 46.48 & 46.04 & 41.73 & 42.25 & 46.55 & 40.71 & 44.98 & 46.74 & 44.72 & 48.20 & 47.18 & 42.24 \\
\hline Fs & 11.64 & 15.63 & 18.17 & 17.50 & 16.23 & 15.88 & 21.08 & 19.91 & 11.75 & 13.08 & 10.19 & 7.91 & 15.26 \\
\hline Mg\# & 79.19 & 74.83 & 71.70 & 70.45 & 72.24 & 74.57 & 65.88 & 69.31 & 79.92 & 77.37 & 82.55 & 85.65 & 73.46 \\
\hline
\end{tabular}

(1-5) plateau, (6-21) Ushkovskii Volcano, (22-25) Krestovskii Volcano, (26) zone of cinder cones. B, basalt; BA, basaltic andesite; TB, trachybasalt; BTA, basaltic trachyandesite; TA, trachyandesite.

microlites of all rocks follow this pattern, supplementing and extending the evolutionary trend of phenocryst compositions, which is characterized by a pronounced tendency toward a higher orthoclase component in the plagioclases, and reaching Ort $10-13 \%$ in oligoclases (see Fig. 8c). The groundmass also contains potassium feldspar (anorthoclase), which is present as microlites in the trachybasalt-trachyandesite series (occasional grains of it are also encountered in basalts), while in basalts and basaltic andesites of normal alkalinity we detected microsegregations of potassium feldspar in the groundmass basis. We also detected K-Na feldspar with concentrations of Ort up to $63 \%$ among trachybasalt microlites and in the matrix of basalt and basaltic trachyandesite (see Fig. 8c, inset).

Overall, the evolution of the mineral compositions as sampled from the Ploskie Sopki massif shows a typical tendency toward successive variation in accordance with increasing silica concentration (see Figs. 5 through 8). The compositions of minerals from all rock varieties are subject to wide variability, are largely similar, and plot in the same fields, which makes their distributions in the diagrams somewhat chaotic, especially for the moderately silicic rocks. Nevertheless, one notes certain compositional differences that man- 
Ti, f.u.

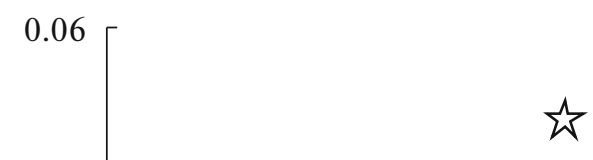

0.04

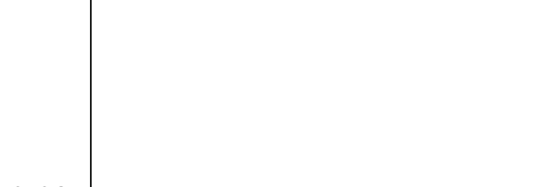

0.02

0

Ti, f.u.

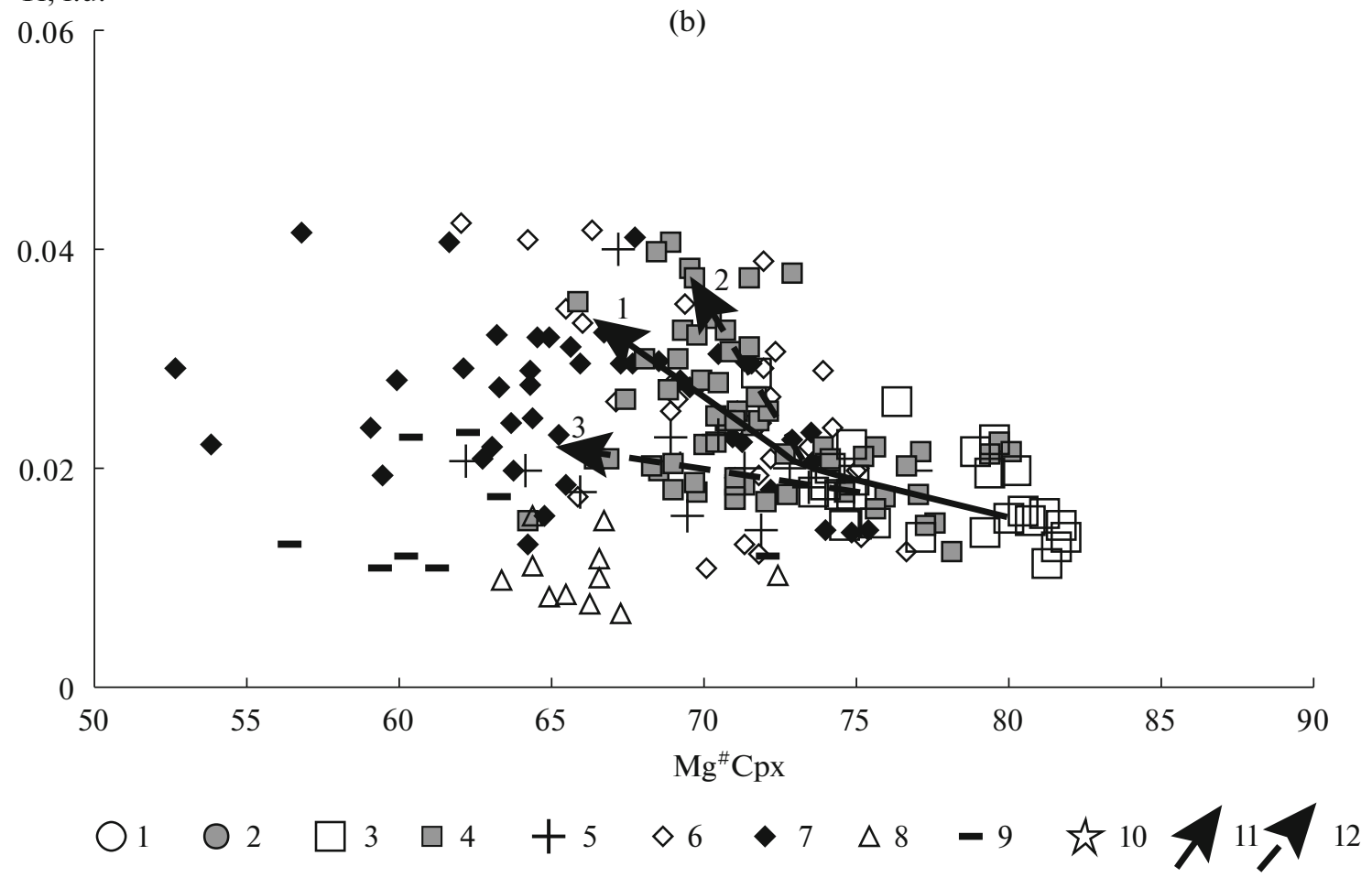

(a)

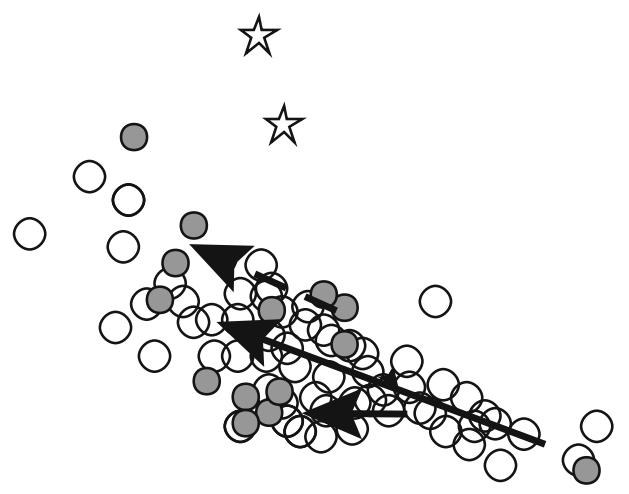

赵

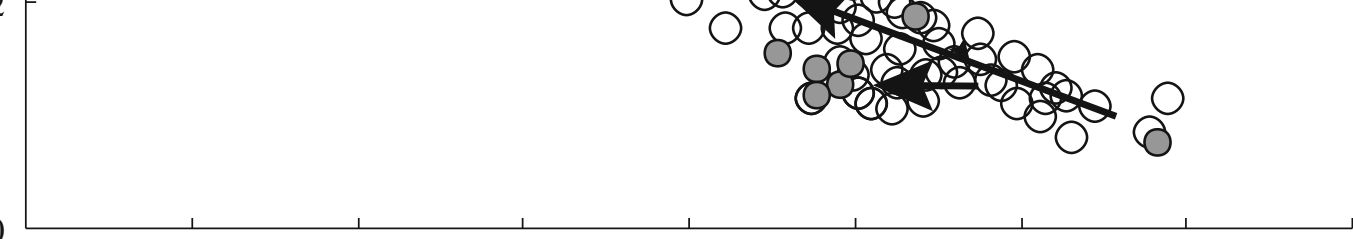

Fig. 7. The $\mathrm{Mg}^{\#} \mathrm{Cpx}-\mathrm{Ti}$ (f.u.) variation diagram for clinopyroxenes from Ploskie Sopki basalts (a), and from basaltic andesites and andesites (b).

$(1-7,11,12)$ for legend consult Fig. 5; (8) pigeonite microlites from rocks of normal alkalinity; (9) pigeonite microlites from rocks of higher alkalinity; (10) pyroxene from a melt inclusion. F.u. stands for formula units.

ifest themselves as appreciable displacements of fields of data points, and as trends of their evolution for rock series of normal and higher alkalinity, respectively (see Figs. 5 through 8). Minerals at the earlier stages of crystallization of basalts from trachybasalts show significantly higher values of Fo in olivines, An in pla- gioclases, $\mathrm{Mg}^{\#} \mathrm{Cpx}$, and lower concentrations of $\mathrm{TiO}_{2}$ compared with minerals from trachybasalts. As well, basalts are characterized by the presence of orthopyroxene and chromopicotites against titanomagnetites in trachybasalts. The typomorphic mineral parageneses of basic Ploskie Sopki rocks, taking mass determi- 
Table 5. Representative compositions of plagioclase (wt \%) from Ploskie Sopki rocks

\begin{tabular}{|c|c|c|c|c|c|c|c|c|c|c|c|c|c|c|c|}
\hline No. & 1 & 2 & 3 & 4 & 5 & 6 & 7 & 8 & 9 & 10 & 11 & 12 & 13 & 14 & 15 \\
\hline Sample no. & \multicolumn{3}{|c|}{2344} & \multicolumn{2}{|c|}{ Plato13-6 } & 2344 & \multicolumn{4}{|c|}{2102} & \multicolumn{4}{|c|}{2112} & 2081 \\
\hline Rock & TB & TB & TB & BTA & BTA & TA & B & B & B & B & B & B & B & B & $\mathrm{BA}$ \\
\hline$\overline{\mathrm{SiO}_{2}}$ & 46.65 & 48.87 & 51.99 & 49.44 & 52.29 & 53.50 & 45.33 & 52.62 & 46.71 & 52.09 & 52.13 & 50.57 & 48.15 & 46.69 & 46.31 \\
\hline $\mathrm{Al}_{2} \mathrm{O}_{3}$ & 32.78 & 31.72 & 29.30 & 31.41 & 29.40 & 27.45 & 33.68 & 28.59 & 32.83 & 29.81 & 29.30 & 30.49 & 32.15 & 33.85 & 33.45 \\
\hline $\mathrm{FeO}$ & 0.72 & 0.80 & 0.64 & 0.73 & 0.79 & 1.20 & 0.81 & 0.67 & 0.87 & 1.09 & 1.15 & 1.06 & 1.08 & 0.88 & 0.87 \\
\hline $\mathrm{CaO}$ & $\mid 16.81$ & 15.21 & 12.35 & 15.27 & 12.87 & 11.18 & 17.81 & 12.11 & 16.86 & 13.44 & 12.87 & 14.33 & 15.5 & 17.24 & 17.53 \\
\hline $\mathrm{Na}_{2} \mathrm{O}$ & 1.88 & 2.65 & 4.13 & 2.98 & 4.11 & 4.74 & 1.40 & 4.41 & 2.00 & 3.83 & 3.94 & 3.26 & 2.39 & 1.37 & 1.62 \\
\hline $\mathrm{K}_{2} \mathrm{O}$ & 0.13 & 0.17 & 0.39 & 0.28 & 0.35 & 0.70 & 0.01 & 0.47 & 0.12 & 0.32 & 0.37 & 0.28 & 0.18 & 0.07 & 0.01 \\
\hline Total & 98.97 & 99.42 & 98.80 & 100.19 & 99.90 & 98.90 & 99.03 & 98.87 & 99.39 & 100.79 & 99.96 & 100.18 & 99.58 & 100.15 & 99.88 \\
\hline ORT & 0.76 & 1.00 & 2.29 & 1.59 & 2.01 & 4.05 & 0.00 & 2.71 & 0.69 & 1.84 & 2.16 & 1.62 & 1.07 & 0.42 & 0.00 \\
\hline $\mathrm{AB}$ & 16.70 & 23.73 & 36.84 & 25.68 & 35.89 & 41.66 & 12.45 & 38.65 & 17.55 & 33.40 & 34.88 & 28.69 & 21.58 & 12.52 & 14.33 \\
\hline $\mathrm{AN}$ & 82.54 & 75.27 & 60.87 & 72.73 & 62.10 & 54.30 & 87.55 & 58.64 & 81.76 & 64.77 & 62.96 & 69.69 & 77.35 & 87.06 & 85.67 \\
\hline No. & 16 & 17 & 18 & 19 & 20 & 21 & 22 & 23 & 24 & 25 & 26 & 27 & 28 & 29 & 30 \\
\hline Sample no. & 2081 & 23 & 31 & & & 2374 & & & & 39 & Ch3-90 & & A86-89 & & 2328 \\
\hline Rock & BA & & TB & TB & TB & TB & TB & TB & BTA & BTA & B & B & B & B & TA \\
\hline$\overline{\mathrm{SiO}_{2}}$ & 52.75 & 52.62 & 52.82 & 47.15 & 48.44 & 49.22 & 49.64 & 50.65 & 48.09 & 53.72 & 46.47 & 49.44 & 51.01 & 54.49 & 54.18 \\
\hline $\mathrm{Al}_{2} \mathrm{O}_{3}$ & 28.11 & 28.91 & 28.73 & 33.31 & 32.61 & 30.91 & 32.07 & 30.40 & 32.00 & 28.64 & 32.28 & 32.15 & 30.71 & 28.01 & 28.00 \\
\hline $\mathrm{FeO}$ & 1.78 & 1.02 & 0.91 & 0.73 & 1.07 & 0.89 & 0.67 & 0.96 & 0.70 & 0.68 & 0.89 & 1.03 & 0.95 & 1.63 & 0.72 \\
\hline $\mathrm{CaO}$ & 11.70 & 12.45 & 12.1 & 16.15 & 15.67 & 14.51 & 14.8 & 13.96 & 15.49 & 11.71 & 17.02 & 15.4 & 14.12 & 12.06 & 11.07 \\
\hline $\mathrm{Na}_{2} \mathrm{O}$ & 4.63 & 3.71 & 3.99 & 2.00 & 2.20 & 3.22 & 2.74 & 3.63 & 2.61 & 4.72 & 1.73 & 2.43 & 3.02 & 4.10 & 4.24 \\
\hline $\mathrm{K}_{2} \mathrm{O}$ & 0.40 & 0.39 & 0.48 & 0.12 & 0.13 & 0.23 & 0.18 & 0.27 & 0.21 & 0.47 & 0.09 & 0.13 & 0.19 & 0.28 & 0.58 \\
\hline Total & 99.57 & 99.25 & 99.19 & 99.46 & 100.12 & 99.08 & 100.10 & 99.98 & 99.18 & 100.02 & 98.65 & 100.77 & 100.17 & 101.03 & 98.92 \\
\hline ORT & 2.32 & 2.37 & 2.87 & 0.72 & 0.78 & 1.33 & 1.07 & 1.54 & 1.22 & 2.69 & 0.52 & 0.78 & 1.14 & 1.68 & 3.55 \\
\hline $\mathrm{AB}$ & 40.76 & 34.20 & 36.30 & 18.18 & 20.10 & 28.27 & 24.82 & 31.50 & 23.08 & 41.04 & 15.45 & 22.04 & 27.58 & 37.45 & 39.48 \\
\hline AN & 56.92 & 63.43 & 60.83 & 81.11 & 79.12 & 70.40 & 74.10 & 66.95 & 75.70 & 56.27 & 84.02 & 77.19 & 71.27 & 60.87 & 56.96 \\
\hline
\end{tabular}

(1-6) plateau, (7-25) Ushkovskii Volcano, (26-29) Krestovskii Volcano, (30) zone of cinder cones. B, basalt; BA, basaltic andesite; TB, trachybasalt; BTA, basaltic trachyandesite; TA, trachyandesite.

nations of phenocrysts into account, are as follows: $\mathrm{Fo}_{88}+\mathrm{CrSp}+\mathrm{Mg}^{\#} \mathrm{Cpx}_{84}+\mathrm{An}_{88}+\mathrm{Mg}^{\#} \mathrm{Opx}_{78}$ for basalts, and $\mathrm{Fo}_{77}+\mathrm{An}_{83} \pm \mathrm{Mg}^{\#} \mathrm{Cpx}_{77}+$ TiMt for trachybasalts. The difference in paragenetic compositions finds an explanation on the basis of the concept of D.S. Korzhinskii, which is based on the differential mobility of components and their activities. According to this concept, at the same temperature an alkaline magma will release minerals that are depleted in strong bases and enriched in weaker bases, thus favoring the crystallization of olivines, pyroxenes that are enriched in iron and depleted in magnesium, and plagioclases that are depleted in calcium compared with rocks of the normal series (Korzhinskii, 1960).

The presence of disequilibrium phenocrysts in basaltic andesites, basaltic trachyandesites, and trachyandesites, as well as phenocrysts that are comparable regarding their enrichment in several elements, with the parageneses of minerals in rocks of greater basicity, provides evidence of their incomplete fractionation during magma crystallization and of mixing of differentiates. In addition, all rocks of higher alka- linity were found to contain minerals from parageneses at earlier phases of basalt crystallization; these minerals are obviously not in equilibrium with the rock of the corresponding silicity; this is a sign of mixing for magmas of different alkalinities.

\section{RESULTS AND DISCUSSION}

Petrochemical data show that volcanic rocks include volcanic associations that contain rocks of different alkalinities and are subject to different tendencies of evolution (see Figs. 2, 3). In one case these form a series of rocks of normal alkalinities: basalt-basaltic andesite-andesite, while in the other they have higher alkalinities: trachybasalt-basaltic and trachyandesite-trachyandesite. All petrochemical types of the above-mentioned series are related via intermediate compositions, which may provide evidence of multistage mixing of magmas.

The existence of two series of volcanic rock evolution is expressed as trends of compositional evolution relative to silicity; trends that are nearly parallel as to 
alkalinity, the concentrations of $\mathrm{FeO}^{*}, \mathrm{CaO}$, and $\mathrm{MgO}$, and by differently oriented trends in $\mathrm{TiO}_{2}$ and $\mathrm{Al}_{2} \mathrm{O}_{3}$ (see Figs. 2, 3), as well as by displacing the field of mineral compositions, and the fact of nearly parallel phenocryst-microlite trends, and by the difference between mineral parageneses of earlier phases in their crystallization (see Figs. 5 through 8). All this implies the comparative independence of two coexisting parent magmas that were generated at different magma sources in a region of the upper mantle. The fact that a deep-seated source of trachybasaltic magma did exist is shown by an alkaline-basaltic composition of the plateau rocks (Churikova et al., 2013, 2015a), which reflects the stage of volcanism that preceded the formation of the Ploskie Sopki massif, and by the essential similarity to the scenario enacted in the Tolbachik Dol volcanism (Braitseva et al., 1984; Flerov et al., 2015; Koloskov et al., 2015; Churikova, 2015a, 2015b). This in turn provides evidence that alkaline magma was involved in the general process of volcanic activity on the Ushkovskii stratovolcano with subsequent synchronous existence of a basaltic and a trachybasaltic magma source.

The linear character of the compositional variation in rocks of different alkalinities with a typical tendency in the correlative alkalies-silicity relationship provides evidence that their evolutionary series were formed as a result of crystallization differentiation of basaltic and trachybasaltic magmas, respectively. Noting the rare presence of high-Mg basalts in the overall volume of the massif rocks (see Fig. 3d), we conclude that the composition of the primary (?) basaltic magma seems to correspond to aluminiferous basalt that was characteristic for the earlier stages in the formation of the massif, while high magnesia basalts are a product of crystallo-gravitational differentiation of magma with subliquidus olivines and pyroxenes deposited in the lower parts of the magma source.

It is probable that the entire diversity of volcanic rocks and the parent magmas of volcanic associations derive from the evolution of parent magmas and their transformation over time and space in accordance with a varying geodynamic setting. At the same time the relationship of all manifestations with a single eruption center, the presence of intermediate rock compositions with a tendency (trend) to rapidly increasing alkalinity, the chaotic character of the distribution of mineral compositions from rocks of different alkalinities and their common fields in the diagrams, the presence of minerals that are not proper to typomorphic parageneses of the rock together all imply interaction of the two magmas as they were ascending, leading to the generation of hybrid magmas (see Fig. 2, Figs. 5-8). One of the features one can use to infer the migration of alkalies during volcanic activity consists in the presence of exotic microsegregations of alkaline feldspar in the groundmass basis of basalts of normal alkalinity, which can be regarded as a manifestation of alkaline metasomatism on an already consolidated rock.

The compositions of mineral parageneses in phenocrysts are discrete (see Figs. 5 through 8); this provides evidence of intermittent stage-like crystallization, hence of a jump-like change in the PT conditions during magma crystallization in the process of the entire volcanic activity that produced the Ploskie Sopki massif. The parent basaltic melts of normal and higher alkalinity moved from the deep-seated sources of their generation to the surface intermittently, producing a set of intermediate chambers in the upper lithosphere where the magmas could mix. The concept of the probable existence of a multi-level set of intermediate chambers during the volcanic process is now accepted by most petrologists and was described in the monograph (Bogatikov et al., 2010). The basaltic and trachybasaltic magmas that were separated in these chambers experienced differentiation, resulting in basalt-basaltic-andesite associations consisting of rocks of different alkalinities at the stratovolcanoes, while the mixing of these magmas produced hybrid magmas. The change in tectonic setting in the region, which manifested itself as the replacement of centraltype volcanism by fissure volcanism gave rise to a disturbance in the magmatic system and favored resumption of volcanic activity; the result was mass effusions of magma during Late Pleistocene through Early Holocene time (Ponomareva et al., 2013), which formed the superimposed zone of cinder cones. The temporal intermission of volcanic activity provided a favorable stable setting for fractional differentiation of the magmas in intermediate chambers, probably localized at higher levels in the lithosphere; this favored the formation of basaltic andesites and andesites of different alkalinities, which prevail among the ejecta from the zone of cinder cones. Garnet grains were encountered in basalts; garnet is a representative mineral of gneisses and crystalline schists (Khanchuk, 1985) and can indicate that the intermediate chamber that produced the basaltic magma of normal alkalinity and its derivatives was located within the Proterozoic crystalline basement. The presence of olivinite xenoliths and of gabbroids that compose the Upper Cretaceous intrusive units in ejecta from the zone of cinder cones implies the existence of intermediate chambers

Fig. 8. The An-Ort variation diagram for feldspars from Ploskie Sopki rocks.

(a, b) phenocrysts and subphenocrysts, (c) feldspar compositions from groundmass. $(1-7,10,11)$ for legend consult Fig. 5; $(8,9)$ compositions of matrix feldspars in the groundmass of basaltoids with normal $(8)$ and higher $(9)$ alkalinity. The solid line contour encloses the compositional field of phenocrysts and subphenocrysts. The inset shows the extension of the An-Ort trend into a region of higher potassium. 

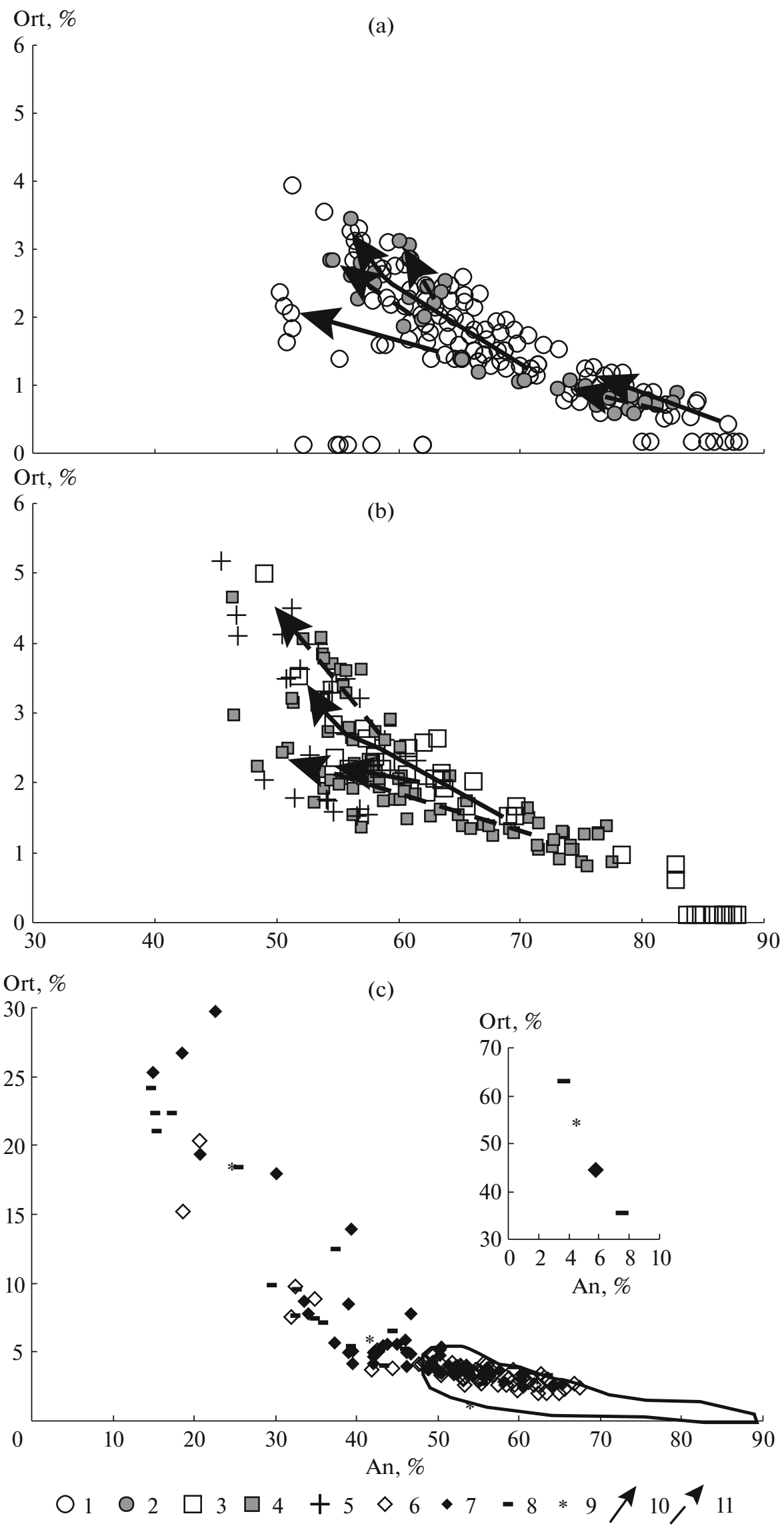


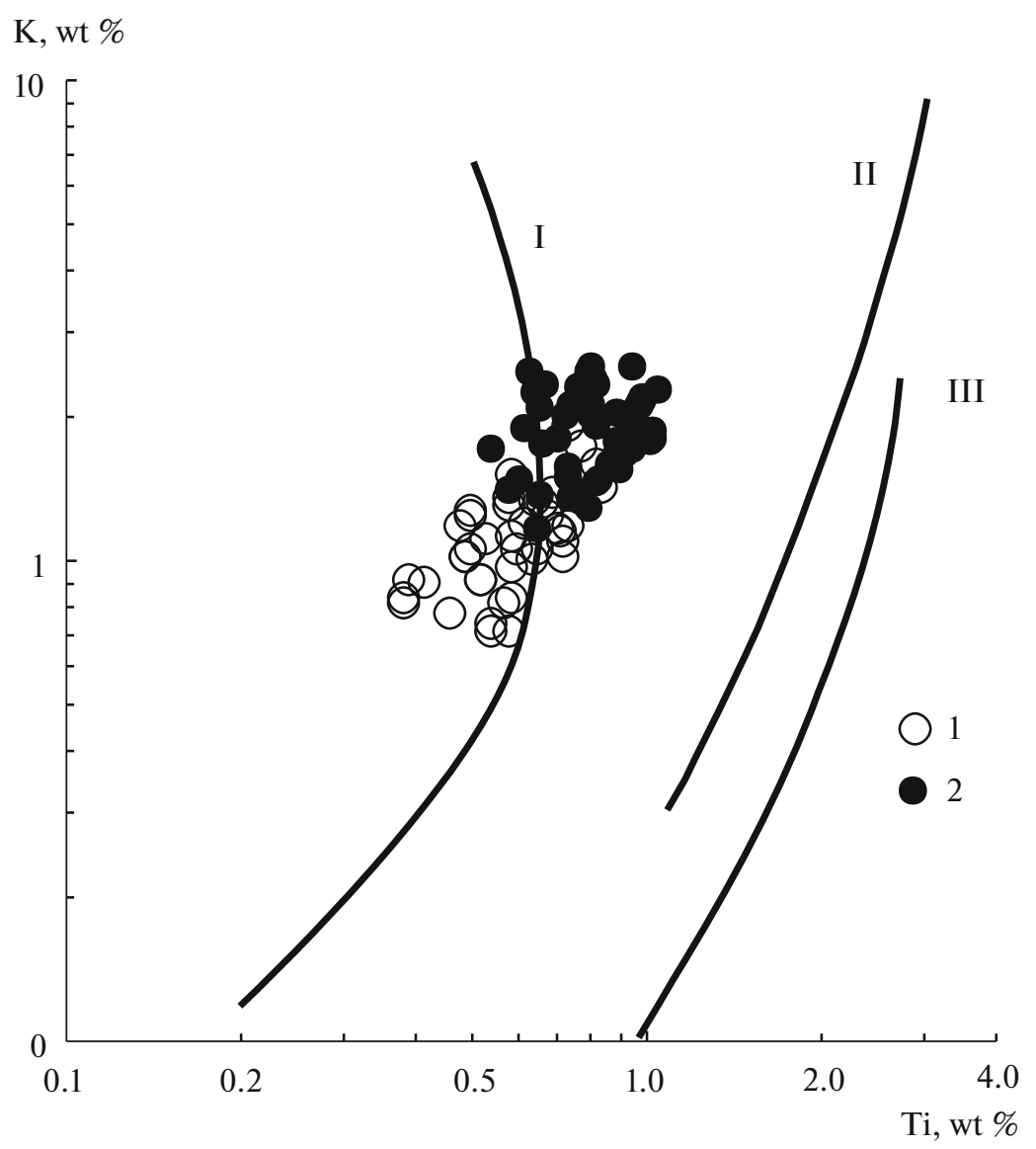

Fig. 9. The Ti-K diagram for Ploskie Sopki volcanic rocks.

(1) rocks of normal alkalinity; (2) rocks of higher alkalinity. The evolutionary trends for basalt compositions (Lutts, 1980):

(I) geosynclinal (island-arc) basalts, (II) basalts of continental rifts, (III) oceanic basalts.

also at higher levels within the Upper Cretaceous volcanogenic-sedimentary rock sequence. Comparing the above with data on the structure of the Kamchatka lithosphere, we believe that these chambers must be at depths of $10-15$ and $5 \mathrm{~km}$, respectively (Balesta et al., 1976, 1984; Moroz and Gontovaya, 2016; Moroz et al., 2016; Nurmukhamedov et al., 2016; Fedotov et al., 2010). It is supposed that trachybasaltic and basaltic magmas that ascend from the deep-seated sources of their generation frequently came to a common intermediate chamber where they mixed. The presence of xenoliths at different depths also corroborates a multi-level set of intermediate chambers.

The long series of differentiates, high concentrations of aluminia $(17-20 \%)$, the prevalence of porphyry textures, the petrochemistry and geochemistry of the rocks (Churikova et al., 2001), as well as the compositions of mineral phases, all provide evidence of an island-arc origin of the lavas in the Ploskie Sopki massif (Frolova et al., 1989; Churikova, 1993). The tendency in the evolution of the rocks expressed in the steep trend of increasing alkalies implies an alkaline fluid being brought into the magmatic system during volcanic activity, which increased the alkalinity in the basaltic magmas. A similar scenario was previously proposed by Churikova et al. (2001) for the high potassium rocks in the Central Kamchatka Depression. The diagram of Fig. 9 shows that the data points for the Ploskie Sopki basalts of both series form a connected cluster, while a displacement of those for the volcanic rocks of higher alkalinity toward the region of riftogenic associations provides evidence of superimposed rifting.

The magma generation processes in the evolution of the Ploskie Sopki and Tolbachik Dol volcanic centers, as expressed in interrelationships between magmas of different alkalinities, are essentially similar; this may indicate the coexistence of independent sources where basaltic and trachybasaltic melts are generated in the upper mantle beneath the entire Klyuchevskoi Volcanic Cluster (Flerov et al., 2015; Churikova et al., 2015a, 2015b; Koloskov et al., 2015). In fact, this concept of two coexisting sources where basaltic and alkaline basaltic magmas are generated, as well as their occurrence at a common volcanic center, is reflected in 
paleovolcanism as polygenic volcanic massifs that were formed in the geological past (Flerov and Seliverstov, 2008; Koloskov et al., 2011; Flerov et al., 2014, 2016).

\section{CONCLUSIONS}

(1) The magmatic activity of the Ploskie Sopki massif is related to the occurrence of basaltic magmas of normal and higher alkalinity. The basaltic volcanism reflects an earlier phase of magmatic activity, viz., the formation of the shield volcano that is the piedmont of the stratovolcanoes. The Ushkovskii stratovolcano inherited the eruption center of the previous phase and began as voluminous eruptions of high alumina basaltic magma of normal alkalinity, while its subsequent activity was characterized by synchronous eruptions proceeding from a common eruption center of basaltic and trachybasaltic magmas that are represented by the differentiated basaltic andesite and the trachybasalt-basaltic-trachyandesite series, respectively. The formation of the stratovolcanoes was terminated by purely basaltic eruptions of Krestovskii Volcano. The volcanism that took place during the terminal phase in the activity of the Ploskie Sopki massif was remarkable in discharging basaltic trachyandesite and trachyandesitic magmas, and to lesser degree basaltic andesite magmas that derived from the trachybasaltic and basaltic magmas, respectively.

(2) The volcanism that has formed the Ploskie Sopki massif was due to the operation of two deepseated sources where melts of different alkalinities were generated, that is, basaltic and trachybasaltic melts, which provides evidence of inhomogeneities in the material composition of the upper mantle substratum. The melts were transported upward to the surface via a set of intermediate chambers, thus favoring differentiation of the magmas as they ascended.

(3) The processes that have been responsible for the evolution of magmas of different alkalinities and for the formation of various types of volcanic rocks are intermittent stage-like crystallization and fractional crystallization in intermediate chambers and their mixing, producing hybrid magmas.

(4) The Ploskie Sopki volcanism is of the islandarc type with some hybrid features and the occurrence of rifting features during the terminal stage of the formation of the massif.

\section{ACKNOWLEDGMENTS}

This work was supported by the Russian Foundation for Basic Research, project nos. 13-05-92104 YaF and 16-55-12040 NNIO_a.

\section{REFERENCES}

Balesta, S.T., Ivanov, B.V., Utnasin, V.K., and Anosov, G.N., Crustal structure beneath the Klyuchevskoi Volcanic Cluster, tectonics and volcanism, in Glubinnoe stroenie, seismichnost' $i$ sovremennaya deyatel'nost' Klyuchevskoi gruppy vulkanov (Deep Structure, Seismicity, and the Present-Day Activity of the Klychevskoi Volcanic Cluster), Vladivostok: DVNTs SSSR, 1976, pp. 7-16.

Balesta, S.T., Zubin, M.I., Kargopol'tsev, A.A., and Fedorchenko, I.A., The deep structure of the eruption area, in Bol'shoe treshchinnoe Tolbachinskoe izverzhenie, 1975-1976 gg., Kamchatka (The Great Tolbachik Fissure Eruption, 1975-1976, Kamchatka), Fedotov, S.A., Ed., Moscow: Nauka, 1984, Ch. XV, pp. 514-536.

Bazanova, L.I., Melekestsev, I.V., Ponomareva, V.V., Dirksen, O.V., and Dirksen, V.G., Late Pleistocene and Holocene volcanic catastrophes in Kamchatka and in the Kuril Islands. Part 1. Types and classes of catastrophic eruptions as the leading components of volcanic catastrophism, J. Volcanol. Seismol., 2016, vol. 10, no. 3, pp. $151-169$.

Bogatikov, O.A., Kovalenko, V.I., and Sharkov, E.V., Magmatizm, tektonika, geodinamika Zemli (The Magmatism, Tectonics, and Geodynamics of the Earth), Trudy IGEM RAN (new series), no. 3, Moscow: Nauka, 2010.

Braitseva, O.A., Melekestsev, I.V., Flerov, G.B., et al., The Holocene Volcanism of the Tolbachik Regional Zone of Cinder Cones, in Bol'shoe treshchinnoe Tolbachinskoe izverzhenie, 1975-1976 gg., Kamchatka (The Great Tolbachik Fissure Eruption, 1975-1976, Kamchatka), Fedotov, S.A., Ed., Moscow: Nauka, 1984, pp. 177-222.

Braitseva, O.A., Melekestsev, I.V., Ponomareva, V.V., et al., Ages of active volcanoes in the Kuril-Kamchatka region, Volcanology and Seismology, 1995, vol. 16, nos. $4 / 5$, pp. $341-370$.

Calkins, J.A., ${ }^{40} \mathrm{Ar} /{ }^{39} \mathrm{Ar}$ geochronology of Khapitsa plateau and Studyonaya river basalts and basaltic andesites in Central Kamchatka depression, Kamchatka, Russia, in Materialy IV mezhdunarodnogo soveshchaniya po protsessam $v$ zonakh subduktsii Yaponskoi, Kurilo-Kamchatskoi i Aleutrskoi dug 'Vzaimosvyaz' mezhdu tektonikoi, seismichnost'yu, mgmoobrazovaniem i izverzheniyami vulkanov v vulkanicheskikh dugakh" (Proc. IV Intern. conference on processes at subduction zones of the Japan, Kuril-Kamchatka, and Aleutian arcs "Interrelationships between Tectonics, Seismicity, Magma Generation, and Volcanic Eruptions at Volcanic Arcs"), Petropavlovsk-Kamchatskii, 2004, pp. 53-54.

Churikova, T.G., The petrochemistry of lavas of Ushkovskii Volcano, in Vulkanologicheskie issledovaniya na Kamchatke (Volcanological Research in Kamchatka), Petropavlovsk-Kamchatskii, 1990. pp. 11-16.

Churikova, T.G., The Geochemistry and Simulation of the Magmatic Process: The Klyuchevskoi Volcanic Cluster, Extended Abstract of Cand. Sci. (Geol.-Mineral.) Dissertation, Moscow State University, 1993.

Churikova, T.G. and Sokolov, S.Yu., The magmatic evolution of Ploskie Sopki Volcano, Kamchatka: Analysis of strontium isotope geochemistry, Geokhimiya, 1993, no. 10 , pp. $1439-1447$.

Churikova, T., Dorendorf, F., and Wörner, G., Sources and fluids in the mantle wedge below Kamchatka, evidence from across-arc geochemical variation, J. Petrol., 2001, vol. 42 , no. 8 , pp. 1567-1593.

Churikova, T.G., Gordeichik, B.N., and Ivanov, B.V., Petrochemistry of Kamen volcano: A comparison with neighboring volcanoes of the Klyuchevskoy group, J. Volcanol. Seismol., 2012, vol. 6, no. 3, pp. 150-171. 
Churikova, T.G., Gordeychik, B.N., Ivanov, B.V., et al., Relationship between Kamen Volcano and the Klyuchevskaya group of volcanoes (Kamchatka), J. Volcanol. Geotherm. Res., 2013, vol. 263, pp. 3-21.

Churikova, T.G., Gordeychik, B.N., Iwamori, H., et al., Petrological and geochemical evolution of the Tolbachik volcanic massif, Kamchatka, Russia, J. Volcanol. Geotherm. Res., 2015a, vol. 307, pp. 156-181.

Churikova, T.G., Gordeychik, B.N., Edwards, B.R., et al., The Tolbachik volcanic massif: A review of the petrology, volcanology and eruption history prior to the 20122013 eruption, J. Volcanol. Geotherm. Res., 2015b, vol. 307, pp. 3-21.

Cox, K.G., Bell, J.D., and Pankhurst, R.J., The Interpretation of Igneous Rocks, Springer, 1979.

Ermakov, V.A., Formatsionnoe raschlenenie chetvertichnykh vulkanicheskikh porod (Formation Stratification of Quaternary Volcanic Rocks), Moscow: Nedra, 1977.

Fedotov, S.A., Zharinov, N.A., and Gontovaya, L.I., The magmatic system of the Klyuchevskaya group of volcanoes inferred from data on its eruptions, earthquakes, deformation, and deep structure, J. Volcanol. Seismol., 2010, vol. 4, no. 1, pp. 1-33.

Flerov, G.B. and Ovsyannikov, A.A., Ushkovskii Volcano, in Deistvuyushchie vulkany Kamchatki (Active Volcanoes of Kamchatka), Moscow: Nauka, 1991, pp. 156-167.

Flerov, G.B. and Seliverstov, V.A., The Cretaceous-Paleogene magmatism of the Sredinnyi Range of Kamchatka: Magma sources, J. Volcanol. Seismol., 2008, vol. 2 , no. 2 , pp. $71-82$.

Flerov, G.B., Perepelov, A.B., Puzankov, M.Yu., Koloskov, A.V., Filosofova, T.M., and Shcherbakov, Yu.D., The space-time relationships between volcanic associations of different alkalinities: The Belogolovskii Massif in Kamchatka's Sredinnyi Range. Part 1. The geology, mineralogy, and petrology of volcanic rocks, J. Volcanol. Seismol., 2014, vol. 8, no. 3, pp. 135-155.

Flerov, G.B., Anan'ev, V.V., and Ponomarev, G.P., The petrogenesis of rocks of the Ostryi and Ploskii Volcanoes and the relationship between volcanic occurrences of basaltic and trachybasaltic magmas in the Tolbachik Dol area, Kamchatka, J. Volcanol. Seismol., 2015, vol. 9, no. 3, pp. 162-181.

Flerov, G.B., Koloskov, A.V., Puzankov, M.Yu., et al., Space-Time relationships between volcanic associations of different alkalinities: The Belogolovskii Massif, Sredinnyi Range, Kamchatka. Part II. Geochemistry of volcanic rocks and magma sources, J. Volcanol. Seismol., 2016, vol. 10, no. 4, pp. 219-241.

Frolova, T.I., Perchuk, L.P., and Burikova, I.A., Magmatizm i preobrazovanie zemnoi kory aktivnykh okrain (Magmatism and Crustal Transformation in Active Margins), Moscow: Nedra, 1989.

Ivanov, B.V., Andezity Kamchatki (Kamchatka Andesites), Moscow: Nauka, 2008.

Khanchuk, A.I., Evolyutsiya drevnei sialicheskoi kory $v$ ostrovoduzhnykh sistemakh Vostochnoi Azii (The Evolution of Ancient Sialic Crust in the East Asian Island Arc Systems), Vladivostok: DVNTs AN SSSR, 1985.

Koloskov, A.V., Flerov, G.B., Perepelov, A.B., Melekestsev, I.V., Puzankov, M.Yu., and Filosofova, T.M., Evolution stages and petrology of the Kekuknai volcanic massif as reflecting the magmatism in backarc zone of Kuril-Kamchatka island arc system. Part 1. Geological position and geochemistry of volcanic rocks, J. Volcanol. Seismol., 2011, vol. 5, no. 5, pp. 312-334.

Koloskov, A.V., Davydova, M.Yu., Izbekov, P.E., et al., The evolution of rock compositions of the New Tolbachik Volcanoes during the 2012-2013 eruption: Mantle control in the on-line format, Tikhook. Geol., 2015, vol. 34, no. 5, pp. 19-39.

Korzhinskii, D.S., Acidity versus alkalinity as the leading factor in magmatic and most-magmatic processes, in Magmatizm i svyaz's nim poleznykh iskopaemykh (Magmatism and Its Relationship to Mineral Deposits), Moscow: Gosgeoltekhizdat, 1960, pp. 21-30.

Lutts, B.G., Geokhimiya okeanicheskogo $i$ kontinental'nogo magmatizma (Geochemistry of Oceanic and Continental Magmatism), Moscow: Nedra, 1980.

Melekestsev, I.V., Kraevaya, T.S., and Braitseva, O.A., Rel'ef $i$ otlozheniya molodykh vulkanicheskikh raionov Kamchatki (Relief and Deposits in Young Volcanic Areas of Kamchatka), Moscow: Nauka, 1970.

Moroz, Yu.F. and Gontovaya, L.I., On lithosphere structure of eastern Kamchatka based on geophysical data, in Materialy ezhegodnoi konferentsii "Vulkanizm $i$ svyazannye s nim protsessy”, posvyashchennoi Dnyu vulkanologa (Proc. Annual Conf. on "Volcanism and Related Processes" Devoted to Volcanologist's Day), Petropavlovsk-Kamchatskii: IViS DVO RAN, 2016, pp. 237-246.

Moroz, Yu.F., Loginov, V.A., and Ulybyshev, I.S., The deep geoelectric section in the junction region among the Sredinnyi Kamchatka Massif, the Ganal Protuberance, and the Central Kamchatka Depression, Vestnik KRAUNTs, Nauki o Zemle, 2016, no. 1, issue 29, pp. 17-34.

Nurmukhamedov, A.G., Nedyad'ko, V.V., Rakitov, V.A., and Lipat'ev, M.S., The boundaries of the Kamchatka lithosphere based on the method of earthquake converted waves, Vestnik KRAUNTs, Nauki o Zemle, 2016, no. 1 , issue 29 , pp. 35-52.

Peccerillo, A. and Taylor, S.R., Geochemistry of Eocene calc-alkaline volcanic rock from the Kastamonu area, Northern Turkey, Contrib. Mineral. Petrol., 1976, vol. 58, pp. 63-81.

Petrograficheskii kodeks Rossii. Magmaticheskie, metamorficheskie, metasomaticheskie, impaktnye obrazovaniya (Petrographic Code of Russia. Magmatic, Metamorphic, Metasomatic, and Impact Formations), 3rd Ed., rev. and suppl., St. Petersburg: VSEGEI, 2009.

Poldervaart, A. and Hess, H.H., Pyroxenes in the crystallization of basaltic magma, J. Geol., 1951, vol. 59, pp. 472489.

Ponomareva,V., Portnyagin, M., Derkachev, A., et al., Early Holocene $M \sim 6$ explosive eruption from Plosky volcanic massif (Kamchatka) and its tephra as a link between terrestrial and marine paleoenvironmental records, Int. J. Earth Sci., 2013, vol. 102, pp. 16731699.

Piip, B.I., Klyuchevskoi Volcano and its eruptions in 19441945 and in the past, Trudy Lab. Vulkanol., 1956, issue 11 (special issue).

Sirin, A.N., O sootnoshenii tsentral'nogo $i$ areal'nogo vulkanizma (On the Relationship between Central and Dispersed Volcanism), Moscow: Nauka, 1968.

Translated by A. Petrosyan 